\title{
Long-term Differences in K Balance Under Rice- wheat Cultivation Alter Potassium Supplying Ability of Soils
}

\section{Zhiyi Zhang}

Hubei Academy of Agricultural Sciences

Dongbi Liu (D672172518@qq.com)

Hubei Academy of Agricultural Sciences

Maoqian Wu

Hubei Academy of Agricultural Sciences

Ying Xia

Hubei Academy of Agricultural Sciences

\section{Fulin Zhang}

Hubei Academy of Agricultural Sciences

\section{Xianpeng Fan}

Hubei Academy of Agricultural Sciences

\section{Research Article}

Keywords: potassium balance, quantity-intensity relationship, non-specific and specific adsorption $\mathrm{K}$, Potential buffering capacity, non-exchangeable and exchangeable $\mathrm{K}$

Posted Date: August 11th, 2021

DOl: https://doi.org/10.21203/rs.3.rs-739403/v1

License: (9) This work is licensed under a Creative Commons Attribution 4.0 International License. Read Full License 


\section{Abstract}

The aims of the present study were to provide scientific bases for rational use of crop straw to substitute chemical potassium (K) input and to protect the ecological environment. The effects of potassium fertilization and straw incorporation on soil $\mathrm{K}$ balance and $\mathrm{K}$ supplying in a long-term (14 years) field experiment. Five treatments were examined: no fertilization and straw (CK); fertilization with no straw return (NPK); only straw return at $6000 \mathrm{~kg} \mathrm{hm}^{-2}$ per season (RS); fertilization with straw return at $3000 \mathrm{~kg}$ $\mathrm{hm}^{-2}$ per season (NPKS); and fertilization with straw return at $6000 \mathrm{~kg} \mathrm{hm}^{-2}$ per season (NPK2S). K composition, $\mathrm{K}$ balance and quantity-intensity $(\mathrm{Q} / \mathrm{I})$ relationship were studied. Under no fertilization or low straw returned conditions, soil $\mathrm{K}$ was unbalance and deficiency seriously. Straw return at $6000 \mathrm{~kg} \mathrm{hm}^{-2}$ per season with fertilization improved the soil potassium supply and $\mathrm{K}$ balance. Long-term $\mathrm{K}$ surplus (4 or 5 years), Compared with NPK, the NPK2S significantly increased non-special adsorption K $\left(\mathrm{K}_{\mathrm{nsa}}\right)$ and nonexchangeable $\mathrm{K}\left(\mathrm{K}_{\mathrm{ne}}\right)$ by 5.7 to $11.2 \mathrm{mg} \mathrm{kg}^{-1}$ and 65.7 to $128.1 \mathrm{mg} \mathrm{kg}^{-1}$, respectively. Q/I relationship showed cropping without straw $\mathrm{K}$ or without fertilizer $\mathrm{K}$ resulted in lower quantity (nonspecifically and specifically held $\mathrm{K}$ i.e. $-\Delta \mathrm{K}_{0}$ and $\mathrm{K}_{\mathrm{x}}$ ) and intensity (equilibrium activity ratio i.e. $\mathrm{CR}_{0}{ }^{\mathrm{K}}$ ) of $\mathrm{K}$ in tested soils. $\mathrm{K}$-fertilization with straw maintain higher exchangeable $\mathrm{K}\left(\mathrm{EK}_{0}\right)$ and a higher difference between $\mathrm{EK}_{0}$ and minimum exchangeable $\mathrm{K}\left(\mathrm{EK}_{\mathrm{min}}\right)$, and would help to prevent depletion in non-exchangeable pool of soil $\mathrm{K}$ under intensive cropping. Additionally, The straw return mainly decreased potential buffering capacity for exchangeable pool ( $\mathrm{PBC}^{\mathrm{K}}{ }_{\mathrm{n}}$ ), $43.92 \%$ to $48.22 \%$ of added $\mathrm{K}$ in soil might be converted to exchangeable pool while it was $25.67 \%$ to $29.19 \%$ be converted to non-exchangeable pool. The contribution of exchangeable $\mathrm{K}$ towards plant $\mathrm{K}$ uptake would be higher in the soil with straw than the soil without straw and the non-exchangeable $\mathrm{K}$ would be the long-term fixed $\mathrm{K}$ as a supplement to the potassium pool. $\mathrm{K}$ fertilizer with $6000 \mathrm{~kg} \mathrm{hm}^{-2}$ straw return in each crop season increased soil available $\mathrm{K}$ and slowly available $\mathrm{K}$. The contribution of exchangeable $\mathrm{K}$ towards plant $\mathrm{K}$ uptake was higher in the soil with straw than without straw and the non-exchangeable $\mathrm{K}$ would be the long-term fixed $\mathrm{K}$ as a supplement to the potassium pool. The findings underlined important of the straw return and contribution for sustain $\mathrm{K}$ supplying ability of soils.

\section{Introduction}

Potassium $(\mathrm{K})$ is an essential nutrient and plays a particularly crucial role in a number of physiological processes vital to growth, yield, quality, and stress resistance of all crops (Zörb et al. 2014; Debarup Das et al.,2021). With the increasing application of nitrogen and phosphorus fertilizers as well as the decrease of organic fertilizer application, large agricultural areas of the world are deficient in K availability, including 3/4 of the paddy soils of China (Wang et al. 2008; Song et al., 2020). Crop straw not only absorbs $\mathrm{K}$ and carries it out of the soils at harvest time, but also an important $\mathrm{K}$ fertilizer resource, and retention of crop straw in fields returns a considerable amount of plant $\mathrm{K}$ to the soil. As the largest traditional agricultural country in the world, China has a large amount of various crop straws with a yield of 674.91Mt and retention of crop straw can provide 11.41 Mt of potassium (Yin et al. 2018). 
The rice-wheat rotation system is one of the largest agricultural production systems, and it covers a total area of 26.7 million hectares (Mha) around the world, including 13.0 Mha for China (Chauhan et al. 2012). Both wheat and rice straws returns are widespread in wheat-rice rotation systems in China because the use of straw returning machines and response to a ban by the Chinese government on field burning of crop straws (Chen et al. 2017). The yield and fertility effects of straw return are the focus of agricultural production (Li et al. 2018; Wang et al. 2018). Yang et al.(2017) reported that ditch-buried rice straw return has the potential to solve the problems of waterlogging stress and that incorporation of total rice straws simultaneously maintains or increases wheat grain yield in the rice-wheat rotation system (Yang et al. 2019). A two-year pot experiment has shown that straw incorporation significantly increases rice yield in most treatments in loamy soil and clay soil (1.6\% 11.9\%) (Zheng et al. 2019). However, there are also some negative effects on production as a large quantity of straw reduces wheat seedling emergence because more soil pores are created by concentrated straw fragments (Yang et al. 2017).

Straw returns to the field can provide potassium needed for growth and improve soil potassium supply capacity and potassium balance. Potassium deficiency is serious in some parts of China, $\mathrm{K}$ balances in some areas are as low as $-500 \mathrm{~kg} \mathrm{hm}^{-2}$ (Tan et al. 2012). Long-term potassium deficiency causes the available $\mathrm{K}$ decreasing by $21 \%$ in a rice-wheat cropping system (Darilek et al. 2009). Approximately $75-$ $80 \%$ of the total $\mathrm{K}$ removal is retained in the straw of crops, indicating that retention of crop straw can substantially replenish the $\mathrm{K}$ requirement of crops (Singh et al. 2018). Yadvinder- Yadvinder-Singh et al. (2004) reported that release of $\mathrm{K}$ from rice straw increases soil $\mathrm{K}$ availability from $50 \mathrm{mg} \mathrm{kg}^{-1}$ soil in the untreated control to $66 \mathrm{mg} \mathrm{kg}^{-1}$ soil in straw-amended treatments within 10 days after incorporation. Promoting the return of straw to the field has great potential to reduce the use of chemical fertilizer. Yin et al. (2018) reported that straw return to farmlands may counterbalance all of the $\mathrm{K}_{2} \mathrm{O}$, the majority of the $\mathrm{P}_{2} \mathrm{O}_{5}$, and a portion of the $\mathrm{N}$ in chemical fertilizers. $\mathrm{K}$ released from maize and rice straw replaces approximately half of the chemical $\mathrm{K}$ fertilizer, depending on the available $\mathrm{K}$ content in the maize-rice cropping system production (Han et al., 2020). In a rice-rapeseed rotation system, the return straw from the rapeseed season replaces $1 / 3-2 / 3$ of potash without reducing the yield of rapeseed, and straw return with potassium fertilizer is beneficial to reduce the soil potassium deficiency (Cheng et al. 2019).

However, the effects of straw return on crop yield, soil fertility and quality have been reported for shortterm experiments in rice-rapeseed system, wheat-maize system or rice system, and only a few experiments have been reported using a wheat-rice system (Yadvinder-Singh et al. 2010; Zhu et al. 2015; Chen et al., 2017). Thus, a long-term field experiment could demonstrate the effects of straw on crop yield dynamics and soil quality (Yang et al. 2016; Wang et al. 2019). In this study, the dynamic effect of amount of straw return and years on crop yield, soil K, and $\mathrm{K}$ balance were investigated by a fixed site field experiment with winter wheat-summer rice rotation for 14 years in the Jianghan Plain. The purpose of this study was to provide scientific bases for rational use of crop straw to substitute chemical K input, to increase crop yield and soil fertility.

\section{Materials And Methods}




\subsection{Experimental site}

The experimental field is located in National Station for Qianjiang Agro-Environment, in Haokou Town $\left(30^{\circ} 22^{\prime} 55.1^{\prime \prime} \mathrm{N}, 112^{\circ} 37^{\prime} 15.4^{\prime \prime} \mathrm{E}\right)$, Qianjiang City, Hubei Province, China. The permission was obtained from National Station for Qianjiang Agro-Environment. The topography is alluvial plain in nature, featuring the tidal soil-type compost of the river alluvial parent material. This region has a humid subtropical monsoon climate. The annual mean temperature and precipitation are $16.1^{\circ} \mathrm{C}$ and $1250 \mathrm{~mm}$, respectively. The basic properties of tested soil at the beginning of the experiment in 2005 are shown in Table 1.

\subsection{Experimental design}

The experiment was conducted using a typical winter wheat-summer rice rotation system. Winter wheat was generally planted in early or mid-November after a rotary tillage and was harvested in mid to late May of the following year. Summer rice was planted in early June after a rotary tillage and harvested in late September or early October. The experiment included the following five treatments: (1) CK, wheat and rice were not fertilized during the seasons, and straw incorporation was also not practised; (2) NPK, wheat and rice were only subjected to chemical fertilization in two seasons with no straw return; (3) RS, the rice and wheat crops were not applied with chemical fertilizer, and straw return was undertaken at an application rate of $6000 \mathrm{~kg} \mathrm{hm}^{-2}$ per season; (4) NPKS, chemical fertilizer and straw return were undertaken with the amount of fertilizer being the same as under the NPK treatment, and straw return was undertaken at an application rate of $3000 \mathrm{~kg} \mathrm{hm}^{-2}$ per season; and (5) NPK2S, chemical fertilizer and straw return were undertaken with the amount of fertilizer being the same as under the NPK treatment, and straw return was undertaken at an application rate of $6000 \mathrm{~kg} \mathrm{hm}^{-2}$ per season. All treatments were arranged in a randomized block design with four replicates, and the plot size was $20 \mathrm{~m}^{2}$ $(5 \mathrm{~m} \times 4 \mathrm{~m})$. The varieties of rice and wheat were Jing Liang You 1377 and Zheng Wheat 9023, purchased from Longping Hi-Tech Seed Industry Co., Ltd and Xiping County Gold Shuo Seed Industry Co., Ltd, respectively.

In the fertilizer treatments, the $\mathrm{N}, \mathrm{P}_{2} \mathrm{O}_{5}$, and $\mathrm{K}_{2} \mathrm{O}$ fertilizers were applied at $120,75,60 \mathrm{~kg} \mathrm{hm}^{-2}$ and 150 , $90,90 \mathrm{~kg} \mathrm{hm}^{-2}$ in the wheat season and rice season, respectively. Each season, $60 \%$ of $\mathrm{N}$, total $\mathrm{P}_{2} \mathrm{O}_{5}$ and $\mathrm{K}_{2} \mathrm{O}$ were surface broadcast applied by hand before sowing as a basal fertilization and incorporated into the $0-15 \mathrm{~cm}$ soil by rotary tillage, and $40 \%$ of $\mathrm{N}$ was broadcast applied as topdressing. The topdressing stage occurred during the jointing stage of wheat and tillering stage of rice. The applied fertilizers were urea $(46 \% \mathrm{~N})$, calcium superphosphate $\left(12 \% \mathrm{P}_{2} \mathrm{O}_{5}\right)$, and potassium chloride $\left(60 \% \mathrm{~K}_{2} \mathrm{O}\right)$.

In each crop season, the crop straw was harvested at ground level, and roots were left in the field. The straw was mixed thoroughly with straw decomposition agent (Wuhan Heyuan Green Organism Co., Ltd., China) after threshing. The straw decomposition agent was mainly composed of typical microbial communities in soils (e.g., bacteria, yeasts, fermenting fungi, and actinomycetes), which were added to facilitate rapid microbial decomposition of the straw for 2 to 3 weeks. After stacking, the wheat or rice 
straw was uniformly incorporated into the surface soil by rotary tillage before rice transplantation or sowing of wheat.

\subsection{Crop harvest, plant sampling and soil sampling}

At annual wheat and rice maturity, each plot was harvested manually, and air-dried grains were weighed. Five rice plants or $50 \mathrm{~cm}$ wheat plants in length were randomly selected from each plot for a separate harvest, and these plants were used for biomass determination. The dry weights of grain and straw were determined after separation and oven drying at $60^{\circ} \mathrm{C}$. For both crops, subsamples of grain and straw were ground and passed through a $0.5 \mathrm{~mm}$ sieve for $\mathrm{K}$ content determination. An aliquot of air-dried soil samples was passed through a 2 and $0.15 \mathrm{~mm}$ sieves. Collection of plants and seeds is in accordance with Chinese law.

\subsection{Plant and soil chemical analysis}

Plant $\mathrm{K}$ in grain and straw was digested using the $\mathrm{H}_{2} \mathrm{SO}_{4}-\mathrm{H}_{2} \mathrm{O}_{2}$ method. Soil pH was determined by electrode method. Alkaline hydrolysis $\mathrm{N}$ was measured using the diffusion method, and available $\mathrm{P}$ was determined by the Lu's method (Lu 1999). Soil available K was extracted using $1 \mathrm{~mol} \mathrm{~L}^{-1}$ ammonium acetate, and water solution $\mathrm{K}\left(\mathrm{K}_{\mathrm{ws}}\right)$ was extracted using a soil-water ratio of 1:5 for $30 \mathrm{~min}$. $\mathrm{Mg}(\mathrm{OAc})_{2}-\mathrm{K}$ was determined by extraction in $0.5 \mathrm{~mol} \mathrm{~L}^{-1} \mathrm{Mg}(\mathrm{OAc})_{2}$. The $\mathrm{Mg}(\mathrm{OAc})_{2}-\mathrm{K}$ consisted of non-special adsorption potassium $\left(\mathrm{K}_{\mathrm{nsa}}\right)$ and $\mathrm{K}_{\mathrm{ws}}$. Special adsorption potassium $\left(\mathrm{K}_{\mathrm{sa}}\right)$ was equal to soil available $\mathrm{K}$ minus $\mathrm{K}_{\mathrm{nsa}}$. Non-exchangeable $\mathrm{K}\left(\mathrm{K}_{\mathrm{ne}}\right)$ was extracted using the hot nitric acid extraction method (Jalali 2006). All K concentrations were determined with a flame photometer (AAnalyst 400, PerkinEImer, US). SOC was determined by potassium dichromate oxidation at $170-180^{\circ} \mathrm{C}$ followed by titration with 0.1 mol L-1 ferrous sulphate (Lu 1999).

\subsection{Quantity/Intensity determination}

Quantity/intensity (Q/I) study was conducted according to the procedure of Beckett (1964). For each replicated plot, separate samples of $2 \mathrm{~g}$ soil were shaken for $30 \mathrm{~min}$ with $20 \mathrm{~mL}$ of $0.01 \mathrm{~mol} \mathrm{~L}^{-1} \mathrm{CaCl}_{2}$ solution having graded concentrations of $\mathrm{K}\left(0\right.$ to $\left.2.50 \mathrm{mmol} \mathrm{L}{ }^{-1}\right)$ and kept overnight at $25 \pm 1^{\circ} \mathrm{C}$ for equilibration. After equilibration, the solution was separated by centrifugation and filtration. The $\mathrm{K}$ concentrations in the filtrates were determined by emission spectroscopy. The soil was washed with $50 \%$ methanol (in water) to remove the entrained $0.01 \mathrm{~mol} \mathrm{~L}-1 \mathrm{CaCl}_{2}$ solution and extracted with $1 \mathrm{~mol} \mathrm{~L}^{-1}$ $\mathrm{NH}_{4} \mathrm{OAc}$ to get the exchangeable $\mathrm{K}$ after equilibration $\left(\mathrm{EK}_{\mathrm{f}}\right)$. The filtrate solutions were analyzed for $\mathrm{K}$ by flame photometer and $\mathrm{Ca}, \mathrm{Mg}$ by atomic absorption spectrophotometer (AAS). For a more detailed description, see paper by Islam et al. (2017).

\subsection{Clay minerals determination}

Organic matter in the soil samples was removed by hydrogen peroxide (30\%). Then, the clay $(<2,000 \mathrm{~nm})$ fractions were collected by sedimentation according to Stokes' Law. Different clay minerals $(<2000,450-$ 2000, 100-450, and 25-100 nm) were identified by an oriented X-ray diffractometer (XRD) (Jackson, 
1979). The oriented samples were examined using powder XRD analysis (D8 Advance, Bruker, Rheinstetten, Germany) with CuKa radiation $(\lambda=1.5418 \AA$ ) generated at $40 \mathrm{kV}$ and $40 \mathrm{~mA}$. Powder samples were recorded in the range of 5 to $50^{\circ} 2 \theta$ at a scanning speed of $1^{\circ} 2 \theta \mathrm{min}^{-1}$.

The mean crystal dimension (MCD) was calculated from full width at half maximum height (FWHM) of illite $d_{001}$ using the Scherrer's equation (Klug and Alexander, 1954), and the average layer number (ALN) was obtained by dividing MCD by the $\mathrm{d}_{001}$ values of illite. The Scherrer's equation was

$\mathrm{MCD}=\frac{\mathrm{K} \gamma}{\mathrm{B} \cos \theta}$, whereK was Scherrer constant ( 0.89 in this study); $\mathrm{B}$ was FWHM of $\mathrm{d}_{001} ; \theta$ was diffraction angle; $\mathrm{Y}$ was $\mathrm{X}$-ray wavelength).

\subsection{Calculation}

In this study, grain output, crop straw output, potash fertilizer input and crop straw input were discussed as affecting soil potassium pool in the soil-crop system, and $\mathrm{K}$ in the atmosphere subsidence and irrigation input were not considered (Tan et al. 2012; Zhao et al. 2014; Bai et al. 2015). The annual straw mulching quantity was strictly controlled, but the annual straw $\mathrm{K}$ content was different, resulting in slightly different annual potassium input amount in the RS, NPKS and NPK2S treatments.

Plant $\mathrm{K}$ uptake was calculated based on plant $\mathrm{K}$ concentration, grain weight and straw weight. The annual soil $\mathrm{K}$ budget was calculated using the following equation:

Soil $\mathrm{K}$ balance $\left(\mathrm{kg} \mathrm{hm}^{-2}\right)=\mathrm{K}$ input $($ fertilizer $\mathrm{K}+$ straw $\mathrm{K})-\mathrm{K}$ removal by crops

Relative yield increase $(\%)=($ Yield of NPK2S - Yield of NPK $) /$ Yield of NPK

\section{Results}

\subsection{Effect of straw return on $\mathrm{K}$ balance}

The $\mathrm{K}$ balance analysis in wheat showed the $\mathrm{K}$ was in a deficit state in most no straw return treatments and that the $\mathrm{K}$ was in a surplus state in the straw return treatments. The $\mathrm{K}$ deficit was $12.8-42.1 \mathrm{~kg} \mathrm{hm}^{-2}$ in the CK treatment (no fertilizer and straw return) (Fig. 1A). The K element was close to the balance of input and output in the NPK treatment with approximate $\mathrm{K}$ deficits or surpluses by $20 \mathrm{~kg} \mathrm{hm}^{-2}$. The soil K surplus was between 100.7 and $126.5 \mathrm{~kg} \mathrm{hm}^{-2}$ in RS. After applying straw and fertilizer to the field, the potassium surplus was $24.2-94.3 \mathrm{~kg} \mathrm{hm}^{-2}$ under a straw return of $3000 \mathrm{~kg} \mathrm{hm}^{-2}$ and was $91.5-154.8 \mathrm{~kg}$ $\mathrm{hm}^{-2}$ under a straw return of $6000 \mathrm{~kg} \mathrm{hm}^{-2}$. These results indicated that a high amount of straw return provided potassium at levels higher than that absorbed by crops, resulting in increased $\mathrm{K}$ surplus in the wheat season.

The $\mathrm{K}$ balance analysis in rice (Fig. 1B) showed that the $\mathrm{K}$ in all treatments was in a deficiency state and that the deficit was much larger in the no chemical $\mathrm{K}$ fertilizer or no straw return treatments. The $\mathrm{K}$ deficit of the CK treatment ranged from $111.3 \mathrm{~kg} \mathrm{hm}^{-2}$ to $134.7 \mathrm{~kg} \mathrm{hm}^{-2}$ and that of the NPK treatment ranged 
from $94.60 \mathrm{~kg} \mathrm{hm}^{-2}$ to $146.1 \mathrm{~kg} \mathrm{hm}^{-2}$. Fertilization alone did not reduce potassium deficiency, but soil $\mathrm{K}$ was also in a state of serious deficiency. In addition, the potassium deficiency of the NPK treatment increased with the increase of crop rotation years. Compared with NPK, the soil K deficiency of NPKS was slightly reduced with 20.2 to $32.1 \mathrm{~kg} \mathrm{hm}^{-2}$. When the amount of straw return was $6000 \mathrm{~kg} \mathrm{hm}^{-2}$ (NPK2S), the soil potassium deficiency was significantly reduced with 45.1 to $78.5 \mathrm{~kg} \mathrm{hm}^{-2}$. These findings indicated that high amount of straw return provided the potassium absorbed by crops and slowed down or reduced the potassium deficit in the soil during the rice season.

The annual $\mathrm{K}$ balance of the wheat-rice system showed that the potassium balance of CK, NPK and NPKS treatment was deficient while that of the RS and NPK2S treatments was in surplus (Fig. 1C). Under the condition of chemical fertilizer only, the average annual $\mathrm{K}$ deficit of wheat-rice rotation was higher, reaching $126.8 \mathrm{~kg} \mathrm{hm}^{-2}$. Under the condition of a small amount of straw return $\left(3000 \mathrm{~kg} \mathrm{hm}^{-2}\right)$, the soil potassium balance was slightly deficient with an average annual $\mathrm{K}$ deficiency of $37.6 \mathrm{~kg} \mathrm{hm}^{-2}$. Under the condition of a higher straw return $\left(6000 \mathrm{~kg} \mathrm{hm}^{-2}\right)$, the soil potassium balance showed a small surplus with an average annual $\mathrm{K}$ surplus of $62.8 \mathrm{~kg} \mathrm{hm}^{-2}$. High straw mulching was beneficial to balance the input and output of potassium literacy, reduce the consumption of soil potassium by crops, alleviate the decrease of soil potassium fertility and maintain the stability of soil potassium fertility.

\subsection{Effect of straw return on soil K content}

Over the 14 cropping rotations, $\mathrm{K}$ pool was significantly affected by straw incorporation (Fig. 2), the $\mathrm{K}_{\mathrm{ws}}$ $\mathrm{K}_{\mathrm{sa}}, \mathrm{K}_{\mathrm{nsa}}$ and $\mathrm{K}_{\mathrm{ne}}$ contents were higher in NPK2S and RS treatments than that of NPK and CK treatments in most years. The content of $K_{w s}$ in NPK2S were significantly higher than that of NPK in 3rd, 11th and 12th cropping periods, that of $\mathrm{K}_{\mathrm{sa}}$ was in 12th and 14th cropping periods. The changes of $\mathrm{K}_{\mathrm{ws}}$ and $\mathrm{K}_{\mathrm{sa}}$ were 3.0 to $7.7 \mathrm{mg} \mathrm{kg}^{-1}$ and 4.3 to $8.2 \mathrm{mg} \mathrm{kg}^{-1}$, respectively. In most years after 6 th cropping rotations, the $\mathrm{K}_{\mathrm{nsa}}$ and $\mathrm{K}_{\mathrm{ne}}$ contents of NPK2S treatment were significantly higher than that of NPK, the changes were 5.7 to $11.2 \mathrm{mg} \mathrm{kg}^{-1}$ and 65.7 to $128.1 \mathrm{mg} \mathrm{kg}^{-1}$, respectively. These results indicated that the straw incorporation with $\mathrm{K}$ fertilizer increased the amount of available $\mathrm{K}$ and direct response of $\mathrm{K}_{\mathrm{nsa}}$ and $\mathrm{K}_{\mathrm{ne}}$ content to straw application was larger than that of $\mathrm{K}_{\mathrm{ws}}$ and $\mathrm{K}_{\mathrm{sa}}$. The amount of straw application and return years were significantly positive correlation with K balance and K pools from 2005 to 2018 (Table 2).

\subsection{Quantity/Intensity relationships (Q/l)}

\subsubsection{Equilibrium $\mathrm{K}$ concentration ratio $\left(\mathrm{CR}_{0} \mathrm{~K}\right)$}

The equilibrium $\mathrm{K}$ concentration ratio $\left(\mathrm{CR}_{0}{ }^{\mathrm{K}}\right)$ is presented in Table 3. There was a large variation in $\mathrm{CR}_{0} \mathrm{~K}$ in the straw return and no straw return soils. In no straw return soil, $\mathrm{CR}_{0}{ }^{\mathrm{K}}$ were 0.66 and $0.74 \times 10^{-3}(\mathrm{~mol}$ $\left.\mathrm{L}^{-1}\right)^{1 / 2}$ in CK and NPK, respectively. In straw return soil, $\mathrm{CR}_{0}{ }^{\mathrm{K}}$ increased 0.31 and $0.43 \times 10^{-3}\left(\mathrm{~mol} \mathrm{~L}^{-1}\right)^{1 / 2}$ 
in RS and NPK2S than CK, respectively. The greatest $\mathrm{CR}_{0}{ }^{\mathrm{K}}$ of $1.09 \times 10^{-3}\left(\mathrm{~mol} \mathrm{~L}^{-1}\right)^{1 / 2}$ was observed in fertilization with straw return $6000 \mathrm{~kg} \mathrm{hm}^{-2}$ per season.

\subsubsection{Labile $K\left(K_{L}\right)$}

The $\mathrm{K}_{\mathrm{L}}$ values in the $\mathrm{CK}$ and NPK soil was about $0.12 \mathrm{cmol} \mathrm{kg}^{-1}$. Compared with no straw return, the $\mathrm{K}_{\mathrm{L}}$ values increased about $0.05 \mathrm{cmol} \mathrm{kg}^{-1}$ after straw return to soil (Table 3). Positive effect of straw $\mathrm{K}$ on $-\Delta \mathrm{K}_{0}$ contents also could be observed, all straw return treatments showed greater $-\Delta \mathrm{K}_{0}$ than the treatments without added straw. In addition, the $\mathrm{K}_{\mathrm{X}}$ of straw return treatments were higher than those without $\mathrm{K}$ fertilizer or without straw return. As a result, cropping without straw $\mathrm{K}$ or fertilizer $\mathrm{K}$ input resulted in lower quantity (nonspecifically and specifically held $K$ i.e. $-\Delta K_{0}$ and $K_{x}$ ) and intensity (equilibrium activity ratio i.e. $\mathrm{CR}_{0}{ }^{\mathrm{K}}$ ) of $\mathrm{K}$ in tested soils.

\subsubsection{Potential buffering capacities (PBC $\left.{ }^{K}\right)$}

The tested soils exhibited different capacities for buffering $\mathrm{K}$ changes in soil solution system (Fig. 3 and Table 4). Potential buffering capacity was higher in CK and NPK soils than RS and NPK2S soil. In CK soil, the total potential buffering capacity $\left(\mathrm{PBC}_{\mathrm{t}}^{\mathrm{K}}\right)$ was $129.87 \mathrm{cmol} \mathrm{kg}^{-1} /\left(\mathrm{mol} \mathrm{L}^{-1}\right)^{1 / 2}$. The PBC ${ }_{\mathrm{t}}$ of NPK soil was $107.44 \mathrm{cmol} \mathrm{kg}^{-1} /\left(\mathrm{mol} \mathrm{L}^{-1}\right)^{1 / 2}$ and was decreased with $22.43 \mathrm{cmol} \mathrm{kg}^{-1} /\left(\mathrm{mol} \mathrm{L}^{-1}\right)^{1 / 2}$. Values of $\mathrm{PBC}^{\mathrm{K}}{ }_{\mathrm{t}}$ in RS soil was $106.37 \mathrm{cmol} \mathrm{kg}^{-1} /\left(\mathrm{mol} \mathrm{L}^{-1}\right)^{1 / 2}$ and NPK2S soil was $93.32 \mathrm{cmol} \mathrm{kg}^{-1} /\left(\mathrm{mol} \mathrm{L}^{-1}\right)^{1 / 2}$, dereased by 23.50 and $36.55 \mathrm{cmol} \mathrm{kg}^{-1} /\left(\mathrm{mol} \mathrm{L}^{-1}\right)^{1 / 2}$ than that of $\mathrm{CK}$, repectively.

Potential buffering capacity for exchangeable pool $\left(\mathrm{PBC}_{\mathrm{e}}^{\mathrm{K}}\right)$ was lower than the non-exchangeable pool $\left(\mathrm{PBC}_{\mathrm{n}}{ }\right)$ in tested soils. The $\mathrm{PBC}_{\mathrm{e}}^{\mathrm{K}}$ in no straw return soils were about $42.00 \mathrm{cmol} \mathrm{kg}{ }^{-1} /\left(\mathrm{mol} \mathrm{L}^{-1}\right)^{1 / 2} \mathrm{while}$ the $\mathrm{PBC}_{\mathrm{n}}^{\mathrm{K}}$ varied from 65.93 to $87.67 \mathrm{cmol} \mathrm{kg}^{-1} /\left(\mathrm{mol} \mathrm{L}^{-1}\right)^{1 / 2}$ being the highest in CK. The PBC ${ }_{\mathrm{e}}$ in $\mathrm{straw}^{\mathrm{N}}$ return soils varied from 44.78 to $52.41 \mathrm{cmol} \mathrm{kg}^{-1} /\left(\mathrm{mol} \mathrm{L}^{-1}\right)^{1 / 2}$ being the highest in RS while $\mathrm{PBC}_{\mathrm{n}}^{\mathrm{K}}$ varied from 48.55 to $53.97 \mathrm{cmol} \mathrm{kg}^{-1} /\left(\mathrm{mol} \mathrm{L}^{-1}\right)^{1 / 2}$ being the highest in RS (Table 4$)$. It indicated the straw return increased a little $\mathrm{PBC}^{\mathrm{K}}{ }_{\mathrm{e}}$ and greatly decreased $\mathrm{PBC}_{\mathrm{n}}^{\mathrm{K}}$.

\subsubsection{Equilibrium exchangeable $\mathrm{K}\left(\mathrm{EK}_{0}\right)$ and conversion of added $K$ to exchangeable $K(\mathbb{D})$}

Simple significant linear regression equation explained the relationship between $E_{f}$ and $\Delta K\left(R^{2}>0.97\right)$ (Fig. 5). Estimated $\mathrm{EK}_{0}$ in unfertilization soil varied from 0.15 to $0.20 \mathrm{cmol} \mathrm{kg}^{-1}$, being the highest in RS (Table 5). Estimated $\mathrm{EK}_{0}$ in fertilization soil varied from 0.17 to $0.21 \mathrm{cmol} \mathrm{kg}^{-1}$, being the highest in NPK2S. It showed straw return could incread $\mathrm{EK}_{0}$ whether in fertilization or unfertilization treatments.

Slopes of the regression lines for no straw return treatments soil ranged from 0.3255 to 0.3903 and that for straw return soil were 0.4392 to 0.4822 (Fig. 4 and Table 5). This result indicates that 32.55-39.03\% of added $\mathrm{K}$ in soil might be converted to exchangeable pool while it was $43.92-48.22 \%$ in straw return 
soil (Table 5). It indicated that long-term straw return could bring great change in exchangeable pool of soil K.

\subsubsection{Equilibrium solution $\mathrm{K}\left(\mathrm{CK}_{0}\right)$ and conversion of added potassium to non-exchangeable pool $(\beta)$}

The relationship between $\Delta \mathrm{K}$ and $\mathrm{K}^{+}$concentration $\left(\mathrm{CK}_{\mathrm{f}}\right)$ in soil solution soils at different treatments were linear (Fig. 5). The intercepts of different regression lines $\left(\mathrm{CK}_{0}\right)$ varied from 0.077 to 0.102 , the straw return treatments were higher than that of no straw return treatments. The significant relationship between DNEK and $\Phi$ showed in Fig. 6. The slope for no straw return soil varied from 0.3241 to 0.3799 while for straw return soil varied from 0.2567 to 0.2919 (Fig. 6). These results indicated that $32.41 \%-$ $37.99 \%$ of the added $\mathrm{K}$ in no straw return soil and $25.67 \%-29.19 \%$ in straw return soil would be converted to non-exchangeable pool(Table 5).

\subsubsection{Critical solution K (CKr) for non-exchangeable K release}

Estimated $\mathrm{CK}_{\mathrm{r}}$ values for no straw return soil ranged from 0.0070 to $0.0074 \mathrm{cmol} \mathrm{L}^{-1}$, however, these values increased with the long term straw return and was 0.0101 to $0.0106 \mathrm{cmol} \mathrm{L}^{-1}$ (Fig. 7 and Table 6). The calculated $\mathrm{EK}_{\mathrm{r}}$ for straw return and no straw return soil were ranged from 0.200 to $0.206 \mathrm{cmol} \mathrm{kg}^{-1}$ and 0.147 to $0.169 \mathrm{cmol} \mathrm{kg}^{-1}$, respectively (Fig. 8 and Table 6). The highest EK $\mathrm{K}_{\mathrm{r}}$ was recorded in fertilization with straw return. Minimum exchangeable $\mathrm{K}^{+}\left(\mathrm{E}_{\mathrm{min}}\right)$ was derived from the intercepts of Fig. 9. The $E_{\min }$ was $0.119-0.139 \mathrm{cmol} \mathrm{kg}^{-1}$ in straw return soil and $0.155-0.158 \mathrm{cmol} \mathrm{kg}^{-1}$ in straw return soil. In no straw return soil $\mathrm{E}_{\mathrm{min}}$ represent about $82 \%$ of the $\mathrm{EK}$, while in straw return soil it was about $77 \%$ of the EK.

\section{Discussion}

\subsection{Change in $\mathrm{K}$ balance and soil $\mathrm{K}$ pool}

According to the Liebig's nutrient restitution theory, soil potassium balance is the key to the sustainable development of agriculture. In this paper, negative K balances under the CK and NPK treatments indicated continuous depletion of soil $\mathrm{K}$ and this situation mainly appeared in rice season (Fig. 1). Under $\mathrm{K}$ deficiency, $\mathrm{K}_{\mathrm{ne}}$ was released and converted into exchangeable potassium for crop absorption (Debarup Das et al., 2019). From 2005 to 2014 years, the $K_{n e}$ contents of NPK and CK treatments appeared decreasing trends under $\mathrm{K}$ depletion (Fig. 2). Because of release of $\mathrm{K}_{\mathrm{ne}}$, the content of exchangeable $\mathrm{K}$ $\left(\mathrm{K}_{\mathrm{sa}}\right.$ and $\left.\mathrm{K}_{\mathrm{nsa}}\right)$ did not show significant decrease. From 2015 to 2018 years, the wheat yield had a greater extent of reduce, the $\mathrm{K}$ balance of wheat was surplus and slow down potassium deficiency of wheat-rice rotation (Fig. 1). The $\mathrm{K}_{\mathrm{ne}}$ increased about $70 \mathrm{mg} \mathrm{kg}^{-1}$ in low yield years (2015 to 2018 years) (Figs. S1 
and S2). Therefore, even though current NPK increased wheat and rice yield than CK, the soil K pool content had a risk of depletion in the rice-wheat rotation when there was an increase in growing years with long term high yield.

Ascribed to the increased $K$ supply of soil due to residue retention, exchangeable $K\left(K_{s a}\right.$ and $\left.K_{n s a}\right)$ and $K_{n e}$ contents in the straw return treatments increased (Fig. 2). Consistent with the results from our study, Yang et al. (2019) also observed that soil available potassium is significantly improved after straw return. Han et al.,(2019) study showed straw return could improve the potential capacity of soil K supplies, straw could be a potential economical $\mathrm{K}$ source for crops, and its replenishment efficiency was estimated to be $47 \%$ for inorganic $\mathrm{K}$ fertilizer under conventional management practices in maize-rice cropping system. Under the condition of surplus potassium, fixation of applied straw $\mathrm{K}$ as $\mathrm{K}_{\mathrm{nsa}}$ and $\mathrm{K}_{\mathrm{ne}}$ were an important progress of soil potassium cycling (Fig. 2). The $\mathrm{K}_{\mathrm{nsa}}$ was readily available $\mathrm{K}$ for crop, $\mathrm{K}_{\mathrm{ne}}$ was slowly available $\mathrm{K}$ that can release to the soil when soil potassium was in shortage (Sharma et al. 2010; Römheld and Kirkby 2010). In this study, the changes of $K_{\text {ne }}\left(65.7\right.$ to $128.1 \mathrm{mg} \mathrm{kg}^{-1}$ ) was higher than that of $\mathrm{K}_{\mathrm{nsa}}\left(5.7\right.$ to $\left.11.2 \mathrm{mg} \mathrm{kg}^{-1}\right)$, indicating the $\mathrm{K}$ mainly fixed as $\mathrm{K}_{\mathrm{ne}}$. In soils, the $\mathrm{K}_{\mathrm{ne}}$ was located at lattice wedge sites, interlayer or surface of weathered 2:1 clay mineral which are selective for $\mathrm{K}$ ions ( $\mathrm{Li}$ et al. 2015). After 14 cropping rotations, the semi-quantitative analysis of clay minerals did not show significant difference, but the crystal parameters of illite changed a lot (Table S1). The FWHM and IB of illite in straw return treatments decreased about $0.3, M C D$ and average layers increased about 10 , indicating the surplus $\mathrm{K}$ fixed by clay minerals (Table S2). In 14 cropping rotations, the $\mathrm{K}_{\text {ne }}$ content of NPK2S was maintained at $640 \mathrm{mg} \mathrm{kg}^{-1}$ and had amount of increase in low yield years. Therefore, fertilization with $6000 \mathrm{~kg} \mathrm{hm}^{-2}$ straw return was an important way to improve soil potassium and sustainable soil development.

\subsection{Quantity-intensity parameters}

\subsubsection{Equilibrium $\mathrm{K}$ concentration ratio $\left(\mathrm{CR}_{0} \mathrm{~K}\right)$}

$\mathrm{Q} / \mathrm{I}$ curve was used to evaluate the dynamics of $\mathrm{K}^{+}$in straw return and not return soils. The $\mathrm{CR}_{0}{ }^{\mathrm{K}}$ provided a satisfactory estimate of $\mathrm{K}^{+}$availability in soil, the greater $\mathrm{CR}_{0}{ }^{\mathrm{K}}$ values indicate the greater amount of plant available $\mathrm{K}$ and a greater $\mathrm{K}^{+}$release into soil solution resulting from a larger pool of soil $\mathrm{K}^{+}$(Panda and Patra 2018). But the plant uptake soil solution $\mathrm{K}$ in rice and wheat growth decrease the $\mathrm{CR}_{0}{ }^{\mathrm{K}}$ values in soil. Islam et al.(2017) found that $\mathrm{K}$ fertilized soil has the ability to provide more solution $\mathrm{K}$ instantly to the growing plants increased $\mathrm{CR}_{0}{ }^{\mathrm{K}}$ values. But in this paper, there was not obvious difference between $\mathrm{CK}$ and NPK (Table 3). Althought NPK was fertilized soil, the $\mathrm{K}$ balance of NPK was deficit and the $\mathrm{CR}_{0}{ }^{\mathrm{K}}$ of NPK was similar with CK as result. In straw return treatments (RS and NPK2S), the soil K balance was surplus and $\mathrm{CR}_{0}{ }^{\mathrm{K}}$ increased by about $0.31 \times 10^{-3}\left(\mathrm{~mol} \mathrm{~L}^{-1}\right)^{1 / 2}$. So, soil potassium balance might be an important factor in determining soil $\mathrm{CR}_{0}{ }^{\mathrm{K}}$, straw return had the ability to provide more solution $\mathrm{K}$ instantly to the growing plants. 
The lower non-specifically available $\mathrm{K}\left(-\Delta \mathrm{K}_{0}\right)$ values in the CK and NPK treatment were related to depletion of soil $K$ caused by the continuous removal of $K$ with plant biomass. The greater $-\Delta K_{0}$ values in the RS and NPK2S treatments indicated greater release of $K$ into soil solution due to straw return. The higher $-\Delta \mathrm{K}_{0}$ and $\mathrm{CR}_{0}{ }^{\mathrm{K}}$ in RS and NPK2S soil was related to the greater accumulation of exchangeable $\mathrm{K}$ (Table 3).

\subsubsection{Potential buffering capacities $\left(\mathrm{PBC}^{\mathrm{K}}\right)$}

Higher the $\mathrm{PBC}^{\mathrm{K}}$, greater depletion of soil $\mathrm{K}$ and greater is the ability of a soil to maintain the intensity of soil solution K under changing environments (Roux and Sumner, 1968; Rupa et al., 2001). The total potential buffering capacity $\left(\mathrm{PBC}_{\mathrm{t}}{ }_{\mathrm{t}}\right)$ of studied soils was lower in straw return soil than no straw returned soil (Table 4). This finding supported the conclusion from other reports that $\mathrm{PBC}^{\mathrm{K}}{ }_{\mathrm{t}}$ of $149 \mathrm{cmol} \mathrm{kg}-1 /(\mathrm{mol}$ $\left.\mathrm{L}^{-1}\right)^{1 / 2}$ in non $\mathrm{K}$ fertilized soil and of $126-136 \mathrm{cmol} \mathrm{kg}^{-1} /\left(\mathrm{mol} \mathrm{L}^{-1}\right)^{1 / 2}$ in $\mathrm{K}$ fertilized soil (Islam et al., 2017). Therefore, increase the input of exogenous potassium would reduce $\mathrm{PBC}^{K}$. Lower $\mathrm{PBC}^{\mathrm{K}}{ }_{\mathrm{t}}$ of $\mathrm{K}$ straw return soil in the present study might also be associated with higher $\mathrm{K}$ saturation of this soil compared to K no straw return soil. Roux and Sumner (1968) also reported increase in $\mathrm{PBC}^{\mathrm{K}}$ with increased $\mathrm{K}$ depletion. Removal of adsorbed $\mathrm{K}$ from non-specific planner surface sites by cropping increased the buffer capacities, indicating that higher energy sites became involved as the number of cropping increased. The $\mathrm{PBC}^{\mathrm{K}}{ }_{\mathrm{e}}$ changed little in different treatments excepted RS, while $\mathrm{PBC}_{n}{ }_{n}$ was lower in straw return soil than no straw returned soil. The results showed that straw potassium existed in the soil in the form of non-exchangeable potassium. The results were also confirmed by the annual evolution of non-exchangeable potassium (Fig. 2).

\subsubsection{Equilibrium exchangeable $\mathrm{K}\left(\mathrm{EK}_{0}\right)$}

Fourteen years of straw return at $6000 \mathrm{~kg} \mathrm{hm}^{-2}$ each season, increased the $\mathrm{EK}_{0}$ of soil. Higher $\mathrm{EK}_{0}$ value indicates the greater capacity of soil to supply $\mathrm{K}$ to the growing plants. The higher $\mathrm{EK}_{0}$ value may have significant importance in arable soils because it can help to maintain proper balance between the solution $\mathrm{K}$ and exchangeable $\mathrm{K}$ in soil (Islam et al.,2017). A soil of higher $\mathrm{EK}_{0}$ controls the release of adsorbed $\mathrm{K}$ from the exchange sites and result in lower $\mathrm{K}$ in soil solution, thus indirectly protecting the soil of a $\mathrm{K}$ loss through leaching. Addition of $\mathrm{K}$ fertilizer in K-deficient soils increases $\mathrm{EK}_{0}$, which in turn results in higher $\mathrm{K}$ in soil solution for plant uptake (Saleque et al., 2009). In this paper, addition of $\mathrm{K}$ fertilizer increased $\mathrm{EK}_{0}$, which further increased by return straw.

The $\mathrm{EK}_{0}$ and $\mathrm{EK}_{\mathrm{min}}$ had to be considered to assess the effect of straw $\mathrm{K}$ and fertilizer on a soil's $\mathrm{K}$ supplying capacity. If $\mathrm{EK}_{\mathrm{r}}$ value is close to $\mathrm{EK}_{0}$, then it is mostly the $\mathrm{K}_{\mathrm{ne}}$ pool contributing to plant nutrition (Jalali and Kolahchi, 2007). The $\mathrm{EK}_{0}$ and $\mathrm{EK}_{\min }$ of the soils in the present study were differences in tested soil (Table 6). So, exchangeable pool of $\mathrm{K}$ in the studied soil plays a vital role in $\mathrm{K}$ nutrition of rice plant. The $\mathrm{EK}_{\min }$ is the portion of exchangeable $\mathrm{K}$ that is extractable with $1 \mathrm{M} \mathrm{NH}_{4} \mathrm{OAc}$ but would not exchange with $\mathrm{Ca}^{2+}$ (Schneider, 1997). Even when activity of soil solution $\mathrm{K}$ approaches zero, $\mathrm{K}$ from EK $\min$ portion 
of exchangeable pool is not released into solution, so it may represent the amount of $\mathrm{K}^{+}$fixed on some clay interlayer sites and is almost unavailable to plants (Islam et al., 2017). Hence, the difference between $\mathrm{EK}_{0}$ and $\mathrm{EK}_{\min }$ would indicate the plant available part of exchangeable $\mathrm{K}$ pool in soil (Debarup Das, 2021). In the present study, the differences between $\mathrm{EK}_{0}$ and $\mathrm{EK}_{\min }$ were higher in straw return soil than no straw return soil, indicating that contribution of exchangeable $\mathrm{K}$ towards plant $\mathrm{K}$ uptake would be higher in the soil with straw than the soil without straw. Application of straw and $\mathrm{K}$ fertilizer was able to maintain higher value of the difference between $\mathrm{EK}_{0}$ and $\mathrm{EK}_{\text {min }}$ than other treatments (Table 6).

Therefore, $\mathrm{K}$-fertilization with straw maintain higher $\mathrm{EK}_{0}$ and a higher difference between $\mathrm{EK}_{0}$ and $\mathrm{EK}_{\text {min }}$, and would help to prevent depletion in non-exchangeable pool of soil $\mathrm{K}$ under intensive cropping. Such findings clearly highlight the importance of adequate $\mathrm{K}$ input through fertilizer with straw on reducing the contribution of soil's nonexchangeable pool towards plant K nutrition.

\subsection{Conversion of added potassium to non-exchangeable pool ( $\beta$ )}

Like seen for $\nabla, K$ fertilization could not bring great change in $\beta$, but $K$ fertilization with straw return increased $\nabla$ and decreased $\beta$. The studied soil had larger $\otimes$ than $\beta$ in straw return soil, much of the applied $\mathrm{K}$ (fertilizer $\mathrm{K}$ and straw $\mathrm{K}$ ) converted to $\mathrm{K}_{\mathrm{ne}}$ in straw return soils. (Table 5 ). The impact of the exchangeable and non-exchangeable pools on $\mathrm{K}^{+}$dynamics in the soil solution system could be indicated though the slope ( $\beta$ ) between the $\triangle$ NEK and the initial constrain indicates (Wang et al., 2004). The larger the $\beta$ the greater the portion of added $\mathrm{K}^{+}$converted to $\mathrm{K}_{\mathrm{ne}}$ (fixed) at positive $\Phi$ or the more fixed $\mathrm{K}^{+}$ released at negative $\Phi$ (Wang et al., 2004). Thus, it can be expected that when $\mathrm{K}^{+}$fertilizer and straw are applied to a soil having a large $\Downarrow$ and a small $\beta$, much of the $\mathrm{K}^{+}$is held as exchangeable and would be available to plants. But in $\mathrm{K}$ fertilizer without straw, $\mathrm{K}$ fertilizer was applied to a less $\mathrm{K}$ supplying soil, $\mathrm{K}^{+}$is held as nonexchangeable, would be available to plants after releasing the short-term fixed $\mathrm{K}$.

\section{Conclusions}

The $\mathrm{K}$ deficit of the rice-wheat rotation was $126.8 \mathrm{~kg} \mathrm{hm}^{-2}$, and the $\mathrm{K}$ deficit mainly appeared in the rice season. High straw return (6000 kg hm${ }^{-2}$ per season) was beneficial to balance the input and output of potassium to achieve an annual potassium surplus by $62.8 \mathrm{~kg} \mathrm{hm}^{-2}$.

The straw incorporation with $\mathrm{K}$ fertilizer increased the amount of available $\mathrm{K}$ and direct response of $\mathrm{K}_{\mathrm{nsa}}$ and $\mathrm{K}_{\mathrm{ne}}$ content to straw application was larger than that of $\mathrm{K}_{\mathrm{ws}}$ and $\mathrm{K}_{\mathrm{sa}}$, The amount of straw application and return years were significantly positive correlation with $\mathrm{K}$ balance and $\mathrm{K}$ pools from

The cropping with straw $\mathrm{K}$ and fertilizer $\mathrm{K}$ input resulted in higher quantity (nonspecifically and specifically held $\mathrm{K}$ i.e. $-\Delta \mathrm{K}_{0}$ and $\mathrm{Ks}$ ) and intensity (equilibrium activity ratio i.e. $\mathrm{CR}_{0}{ }^{\mathrm{K}}$ ) of $\mathrm{K}$ in tested soils. The greatest $\mathrm{CR}_{0}{ }^{\mathrm{K}}$ of $1.09 \times 10^{-3}\left(\mathrm{~mol} \mathrm{~L}^{-1}\right)^{1 / 2},-\Delta \mathrm{K}_{0}$ of $0.101 \mathrm{cmol} \mathrm{kg}^{-1}$ and $\mathrm{K}_{\mathrm{X}}$ of $0.069 \mathrm{cmol} \mathrm{kg}^{-1}$ were observed in fertilization with straw return $6000 \mathrm{~kg} \mathrm{hm}^{-2}$ per season. 
The straw return increased a little $\mathrm{PBC}^{\mathrm{K}}{ }_{\mathrm{e}}$ and greatly decreased $\mathrm{PBC}^{\mathrm{K}}{ }_{n}, 43.92-48.22 \%$ of added $\mathrm{K}$ in soil might be converted to exchangeable pool while it was $25.67-29.19 \%$ be converted to non-exchangeable pool. The contribution of exchangeable $K$ towards plant $K$ uptake would be higher in the soil with straw than the soil without straw and the non-exchangeable $K$ could be fixed on a long term.

\section{Declarations}

\section{Acknowledgments}

This research was supported by the The National Natural Science Foundation of the People's Republic of China (41907071), The National Key Research and Development Program of China (2016YFD0300902) and Hubei Academy of Agricultural Sciences Major Achievements Cultivation Project (2017CGPY03)

\section{References}

1. Bai, Y. L. et al. Effects of long-term full straw return on yield and potassium response in wheat-maize rotation. J. Integr. Agric, 14, 2467-2476 https://doi.org/10.1016/S2095-3119(15)61216-3 (2015).

2. Beckett, P. H. T. The immediate Q/I relations of labile potassium in the soil. Eur. J. Soil Sci, 19, 9-23 (1964).

3. Chauhan, B. S., Mahajan, G., Sardana, V., Timsina, J. \& Jat, M. L. Productivity and sustainability of the rice-wheat cropping system in the indo-gangetic plains of the indian subcontinent: Problems, opportunities, and strategies. Adv. Agron, 117, 315-369 https://doi.org/10.1016/B978-0-12-3942784.00006-4 (2012).

4. Chen, Z. et al. Changes in soil microbial community and organic carbon fractions under short-term straw return in a rice-wheat cropping system. Soil Tillage Res, 165, 121-127 https://doi.org/10.1016/j.still.2016.07.018 (2017).

5. Cheng, W. et al. Effect of continuous straw incorporation substitute for K-fertilizer on crop yield and soil potassium balance. Soils Fertilizers Sci. China, 5, 72-78 (in Chinese). (2019).

6. Darilek, J. L. et al. Changes in soil fertility parameters and the environmental effects in a rapidly developing region of China. Agric. Ecosyst. Environ, 8, 31-37 https://doi.org/10.1016/j.agee.2008.10.002 (2009).

7. Debarup Das, Dwivedi, B. S. et al. Long-term differences in nutrient management under intensive cultivation alter potassium supplying ability of soils. Geoderma, 393, 114983 https://doi.org/10.1016/j.geoderma.2021.114983 (2021).

8. Debarup Das et al. Potassium supplying capacity of a red soil from eastern india after forty-two years of continuous cropping and fertilization., 341, 76-92 (2019).

9. Du Preez, C. C. \& Bennie, A. T. P. Concentration, accumulation and uptake rate of macro-nutrients by winter wheat under irrigation. South African J. Plant Soil, 8, 31-37 https://doi.org/10.1080/02571862.1991.10634576 (1991). 
10. Han, Y. et al. Straw return increases crop grain yields and K-use efficiency under a maize-rice cropping system. Crop J, https://doi.org/10.1016/j.cj.2020.04.003 (2020).

11. Han, Y. et al. Straw return increases crop grain yields and K-use efficiency under a maize-rice cropping system. Crop J, https://doi.org/10.1016/j.cj.2020.04.003 (2020).

12. Islam, A., Karim, A., Solaiman, A., Islam, M. S. \& Saleque, M. A. Eight-year long potassium fertilization effects on quantity/intensity relationship of soil potassium under double rice cropping. Soil \& Tillage Research, 169, 99-117 (2017).

13. Jackson, M. L. Soil chemical analysis-advanced course 2nd edn (University of Wisconsin, Madison, WI, 1979).

14. Jalali, M. Kinetics of non-exchangeable potassium release and availability in some calcareous soils of western Iran., 135, 63-71 https://doi.org/10.1016/j.geoderma.2005.11.006 (2006).

15. Jalali, M. \& Kolahchi, Z. Short-term potassium release and fixation in some calcareous soils. J. Plant Nutr. Soil Sci, 170, 530-537 (2007).

16. Klug, H. P. \& Alexander, L. E. 1954. X-ray diffraction procedures for polycrystalline and amorphous materials. New York.

17. Li, H., Dai, M., Dai, S. \& Dong, X. Current status and environment impact of direct straw return in China's cropland - A review. Ecotoxicol. Environ. Saf, 159, 293-300 https://doi.org/10.1016/j.ecoenv.2018.05.014 (2018).

18. Li, T., Wang, H., Zhou, Z., Chen, X. \& Zhou, J. A nano-scale study of the mechanisms of nonexchangeable potassium release from micas. Appl. Clay Sci, 118, 131-137 https://doi.org/10.1016/j.clay.2015.09.013 (2015).

19. Lu, R. K. Soil agrochemical analysis method (China Agricultural Press, Beijing, 1999).

20. Panda, R. \& Patra, S. K. Quantity-intensity relations of potassium in representative coastal soils of eastern India., 332, 198-206 (2018).

21. Römheld, V. \& Kirkby, E. A. Research on potassium in agriculture: Needs and prospects. Plant Soil, 335, 155-180 https://doi.org/10.1007/s11104-010-0520-1 (2010).

22. Roux, J. L. \& Summer, M. E. Labile potassium in soils, I: Factors affecting the quantity-intensity (Q/I) parameters. Soil Sci, 106, 35-41 (1968).

23. Rupa, T. R., Srivastava, S., Swarup, A. \& Singh, D. Potassium supplying power of a Typic Ustochrept profile using quantity/intensity technique in a long-term fertilized plot. J. Agr. Sci, 137 (2), 195-203 https://doi.org/10.1017/ (2001).

24. Saleque, M. A., Anisuzzaman, M. \& Moslehuddin, A. Z. M. Quantity-intensity relationships and potassium buffering capacity of four Ganges river floodplain soils. Commun. Soil Sci. Plant Anal, 40 (7-8), 1333-1349 (2009).

25. Schneider, A. Release and fifixation of potassium by loamy soil as affected by initial soil water content and potassium status of soil samples. Eur. J. Soil Sci, 48, 263-271 (1997). 
26. Sharma, A., Jalali, V. K. \& Arora, S. Non-exchangeable potassium release and its removal in foot-hill soils of North-west Himalayas., 82, 112-117 https://doi.org/10.1016/j.catena.2010.05.009 (2010).

27. Singh, V. K. et al. Effect of tillage and crop establishment, residue management and $\mathrm{K}$ fertilization on yield, $\mathrm{K}$ use efficiency and apparent $\mathrm{K}$ balance under rice-maize system in north-western India. $F$. Crop. Res, 224, 1-12 https://doi.org/10.1016/j.fcr.2018.04.012 (2018).

28. Song, X. D., Liu, F., Wu, H. Y., Cao, Q. \& Zhang, G. L. Effects of long-term k fertilization on soil available potassium in east china., $188,104412(2020)$.

29. Tan, D., Jin, J., Jiang, L., Huang, S. \& Liu, Z. Potassium assessment of grain producing soils in North China. Agric. Ecosyst. Environ, 148, 65-71 https://doi.org/10.1016/j.agee.2011.11.016 (2012).

30. Wang, $\mathrm{H}$. et al. Effects of long-term application of organic fertilizer on improving organic matter content and retarding acidity in red soil from China. Soil Tillage Res, 83, 203-218 https://doi.org/10.1016/j.still.2019.104382 (2019).

31. Wang, H. J. et al. Major nutrient balances in small-scale vegetable farming systems in peri-urban areas in China. Nutr. Cycl. Agroecosystems, 195, 104382 https://doi.org/10.1007/s10705-007-9157-8 (2008).

32. Wang, J. J., Harrell, D. L. \& Bell, P. F. Potassium buffering characteristics of three soils low in exchangeable potassium. Soil Sci. Soc. Am. J, 68, 654-661 (2004).

33. WANG, S. et al. The efficiency of long-term straw return to sequester organic carbon in Northeast China's cropland. J. Integr. Agric, 17, 436-448 https://doi.org/10.1016/S2095-3119(17)61739-8 (2018).

34. Yadvinder-Singh, Gupta, R. K., Jagmohan-Singh, G. S. \& Gobinder-Singh, Ladha, J. K. Placement effects on rice residue decomposition and nutrient dynamics on two soil types during wheat cropping in rice-wheat system in northwestern India. Nutr. Cycl. Agroecosystems, 88, 471-480 https://doi.org/10.1007/s10705-010-9370-8 (2010).

35. Yadvinder-Singh, B. S. et al. Long-term effects of organic inputs on yield and soil fertility in the ricewheat rotation. Soil Sci. Soc. Am. J, 68, 845-853 https://doi.org/10.2136/sssaj2004.8450 (2004).

36. Yang, $\mathrm{H}$. et al. Long-term ditch-buried straw return alters soil water potential, temperature, and microbial communities in a rice-wheat rotation system. Soil Tillage Res, 163, 21-31 https://doi.org/10.1016/j.still.2016.05.003 (2016).

37. Yang, H. et al. Waterlogging reduction and wheat yield increase through long-term ditch-buried straw return in a rice-wheat rotation system. F. Crop. Res, 209, 189-197 https://doi.org/10.1016/j.fcr.2017.05.012 (2017).

38. Yang, $\mathrm{H}$. et al. Ditch-buried straw return: A novel tillage practice combined with tillage rotation and deep ploughing in rice-wheat rotation systems. Adv. Agron, 154, 257-290 https://doi.org/10.1016/bs.agron.2018.11.004 (2019).

39. Yin, H., Zhao, W., Li, T., Cheng, X. \& Liu, Q. Balancing straw returning and chemical fertilizers in China: Role of straw nutrient resources. Renew. Sustain. Energy Rev, 81, 2695-2702 https://doi.org/10.1016/j.rser.2017.06.076 (2018). 
40. Zhao, S. et al. Long-term effects of potassium fertilization and straw return on soil potassium levels and crop yields in north-central China. F. Crop. Res, 169, 116-122

https://doi.org/10.1016/j.fcr.2014.09.017 (2014).

41. Zheng, J. et al. Effects of straw incorporation on crop yield and dissolved organic carbon concentration at rice growing season in rice-wheat rotation cropping system. Chinese J. Eco-Agri, 27, 431-440 (in Chinese). (2019).

42. Zörb, C., Senbayram, M. \& Peiter, E. Potassium in agriculture - Status and perspectives. J. Plant Physiol, 171, 656-669 https://doi.org/10.1016/j.jplph.2013.08.008 (2014).

\section{Tables}

Table 1 Selected physicochemical properties of soils studied

\begin{tabular}{|c|c|}
\hline Properties & Value \\
\hline Particle size analysis (Texture) & Light loam \\
\hline $\mathrm{pH}$ (soil:water $=1: 2.5$ ) & 7.1 \\
\hline Soil organic matter $\left(\mathrm{g} \mathrm{kg}^{-1}\right)$ & 20.6 \\
\hline Total N (\%) & 1.5 \\
\hline Alkali-hydrolyzable $\mathrm{N}\left(\mathrm{mg} \mathrm{kg}^{-1}\right)$ & 121.0 \\
\hline Olsen-P (mg kg $\left.{ }^{-1}\right)$ & 19.2 \\
\hline Available $\mathrm{K}\left(\mathrm{mg} \mathrm{kg}^{-1}\right)$ & 59.1 \\
\hline Bulk density $\left(\mathrm{g} \mathrm{cm}^{-3}\right)$ & 1.2 \\
\hline Smectite (\%) & 4 \\
\hline HIV and vermiculite (\%) & 20 \\
\hline Illite (\%) & 27 \\
\hline Kaolinite (\%) & 49 \\
\hline
\end{tabular}

HIV, hydroxyl-interlayered minerals.

Table 2 Results of ANOVA on the effects of $\mathrm{K}$ rate and year and their interactions $\mathrm{K}$ balance and $\mathrm{K}$ pools from 2005 to 2018. 


\begin{tabular}{|llllll|}
\hline Effect & K balance & $\mathrm{K}_{\mathrm{ws}}$ & $\mathrm{K}_{\mathrm{nsa}}$ & $\mathrm{K}_{\mathrm{sa}}$ & $\mathrm{K}_{\mathrm{ne}}$ \\
\hline Straw K rate & $465.4^{\star \star \star}$ & $96.0^{\star \star \star}$ & $59.9^{\star \star \star}$ & $12.0^{\star \star}$ & $15.1^{\star \star}$ \\
\hline Year & $25.3^{\star \star \star}$ & $51.1^{\star \star \star}$ & $17.3^{\star \star \star}$ & $10.6^{\star \star \star}$ & $46.5^{\star \star \star}$ \\
\hline straw K×Year & $0.9^{\mathrm{ns}}$ & $1.54^{\mathrm{ns}}$ & $1.5^{\mathrm{ns}}$ & $1.2^{\mathrm{ns}}$ & $1.6^{\mathrm{ns}}$ \\
\hline
\end{tabular}

Straw $\mathrm{K}$ rate, different amount of straw return, 0,3000 and $6000 \mathrm{~kg} \mathrm{hm}^{-2}$ per season; $\mathrm{K}_{\mathrm{ws}}$, water soluble potassium; $\mathrm{K}_{\mathrm{nsa}}$, Non-special adsorption potassium; $\mathrm{K}_{\mathrm{sa}}$, special adsorption potassium; $\mathrm{K}_{\mathrm{ne}}$, nonexchangeable potassium; $F$ values and significance levels are given ( $n s p>0.05,{ }^{\star} p<0.05,{ }^{*} p<0.01$, $* \star \star$ $\mathrm{p}<0.001)$.

Table 3 Equilibrium $\mathrm{K}$ concentration ratio $\left(\mathrm{CR}_{0}{ }^{\mathrm{K}}\right)$, labile $\mathrm{K}\left(\mathrm{K}_{\mathrm{L}}\right)$, nonspecifically available $\mathrm{K}\left(-\Delta \mathrm{K}_{0}\right)$ and specifically available $K\left(K_{X}\right)$ of rice soil after 14 years of $K$ fertilization

\begin{tabular}{lllll} 
Treatment & $\mathrm{CR}_{0} \mathrm{~K}_{\times} \times 10^{-3}$ & $\mathrm{~K}_{\mathrm{L}}$ & $-\Delta \mathrm{K}_{0}$ & $\mathrm{~K}$ \\
& $\left(\mathrm{~mol} \mathrm{~L}^{-1}\right)^{1 / 2}$ & \multicolumn{2}{l}{$\mathrm{cmol} \mathrm{kg}^{-1}$} & \\
\hline $\mathrm{CK}$ & 0.66 & 0.12 & 0.086 & 0.034 \\
\hline $\mathrm{NPK}$ & 0.74 & 0.13 & 0.080 & 0.050 \\
\hline $\mathrm{RS}$ & 0.97 & 0.17 & 0.103 & 0.067 \\
\hline NPK2S & 1.09 & 0.17 & 0.101 & 0.069
\end{tabular}

CK, no fertilization and straw; NPK, recommended fertilization and no straw return; RS, no fertilization and straw return to fields with $6000 \mathrm{~kg} \mathrm{hm}^{-2}$, NPKS, recommended fertilization and straw return to fields with $3000 \mathrm{~kg} \mathrm{hm}^{-2}$; and NPK2S, recommended fertilization and straw return to fields with $6000 \mathrm{~kg}$ $\mathrm{hm}^{-2}$

Table 4 Estimated equilibrium potential buffering capacity of $\mathrm{K}\left(\mathrm{PBC}^{\mathrm{K}}\right)\left[\mathrm{cmol} \mathrm{kg}^{-1} /\left(\mathrm{mol} \mathrm{L}^{-1}\right)^{1 / 2}\right]$ of rice soil after 14 year of $\mathrm{K}$ fertilization- 


\begin{tabular}{llll} 
Treatment & $\mathrm{PBC}_{\mathrm{t}}$ & $\mathrm{PBC}_{\mathrm{e}} \mathrm{PBC}_{\mathrm{n}}$ \\
\cline { 2 - 4 } & \multicolumn{3}{c}{$\mathrm{cmol} \mathrm{kg}^{-1} /\left(\mathrm{mol} \mathrm{L}^{-1}\right)^{1 / 2}$} \\
\hline $\mathrm{CK}$ & 129.87 & 42.20 & 87.67 \\
\hline NPK & 107.44 & 41.50 & 65.93 \\
\hline RS & 106.37 & 52.41 & 53.97 \\
\hline NPK2S & 93.32 & 44.78 & 48.55
\end{tabular}

$\mathrm{PBC}_{\mathrm{e}}^{\mathrm{K}}=$ potential buffering capacity due to exchangeable $\mathrm{K} ; \mathrm{PBC}^{\mathrm{K}}{ }_{\mathrm{n}}=$ potential buffering capacity due to non-exchangeable $\mathrm{K} ; \mathrm{PBC}^{\mathrm{K}}{ }_{\mathrm{t}}=$ total potential buffering capacity.

Table 5 Effect of long-term straw return on the equilibrium exchangeable $\mathrm{K}\left(\mathrm{EK}_{0}\right)$, equilibrium solution $\mathrm{K}$ $\left(\mathrm{CK}_{0}\right)$ and magnitude of the conversion of added $\mathrm{K}$ to exchangeable $\mathrm{K}(\mathrm{a})$ and non-exchangeable $\mathrm{K}(\mathrm{b})$.

\begin{tabular}{lllll} 
Treatment & $\mathrm{EK}_{0} \mathrm{Cmol} \mathrm{kg}^{-1}$ & $\mathrm{a} \%$ & $\mathrm{CK}_{0} \mathrm{Cmol} \mathrm{kg}^{-1}$ & $\mathrm{~b} \%$ \\
CK & 0.15 & 32.55 & 0.077 & 37.99 \\
NPK & 0.17 & 39.03 & 0.088 & 32.41 \\
\hline RS & 0.20 & 43.92 & 0.093 & 29.19 \\
NPK2S & 0.21 & 48.22 & 0.102 & 25.67
\end{tabular}

Table 6 Effect of long-term $\mathrm{K}$ fertilization on the critical value of solution $\mathrm{K}\left(\mathrm{CK}_{\mathrm{r}}\right)$, exchangeable $\mathrm{K}\left(\mathrm{EK}_{\mathrm{r}}\right)$ and minimum exchangeable $\mathrm{K}\left(\mathrm{E}_{\min }\right)$ of rice soil

\begin{tabular}{llllll} 
Treatment & $\mathrm{CK}_{\mathrm{r}} \mathrm{cmol} \mathrm{kg}$ & $\mathrm{EK}_{\mathrm{r}} \mathrm{cmol} \mathrm{kg}$ & $\mathrm{E}_{\min } \mathrm{cmol} \mathrm{kg}^{-1}$ & of \% EK & $\mathrm{EK}_{0}-\mathrm{E}_{\min } \mathrm{cmol} \mathrm{kg}^{-1}$ \\
\hline $\mathrm{CK}$ & 0.0070 & 0.147 & 0.119 & 81.20 & 0.031 \\
\hline $\mathrm{NPK}$ & 0.0074 & 0.169 & 0.139 & 82.47 & 0.031 \\
\hline RS & 0.0101 & 0.200 & 0.155 & 77.65 & 0.045 \\
\hline NPK2S & 0.0106 & 0.206 & 0.158 & 76.72 & 0.052
\end{tabular}

CKr, it can be obtained by dividing the intercept by slope of the regression equation of DNEK (in the $y$ axis) and CKf (x-axis) (Fig.7); Ekr, it was obtained by interpolation from the relation $\mathrm{EK}_{\mathrm{f}}=\mathrm{f}\left(\mathrm{CK}_{\mathrm{f}}\right)$ at $\mathrm{CKr}$ (Fig. 8), putting the value of $\mathrm{CKr}$ in the place of $\mathrm{x}$, corresponding value of $\mathrm{EK}_{\mathrm{f}}$ was obtained, which is essentially EKr.

\section{Figures}



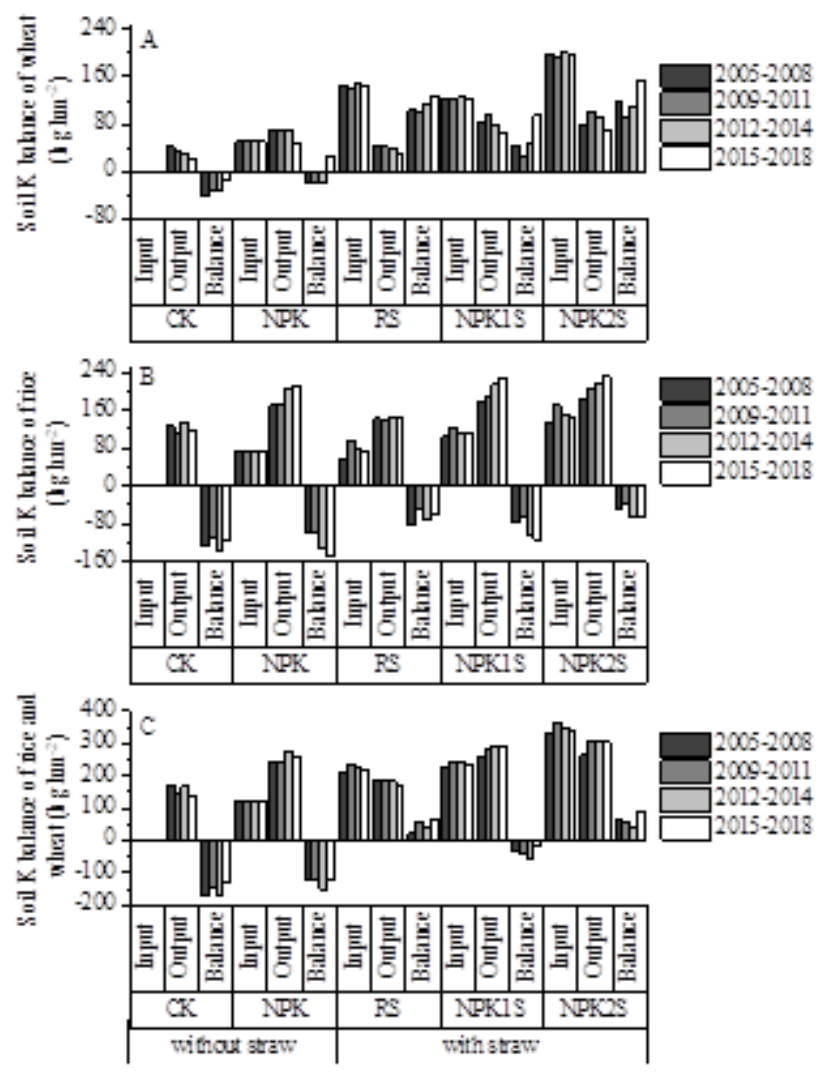

Figure 1

Characteristics of soil potassium balance for different cropping rotation periods from 2005 to 2018. (CK, no fertilization and straw; NPK, recommended fertilization and no straw return; RS, no fertilization and straw return to fields with $6000 \mathrm{~kg} \mathrm{hm}-2$, NPKS, recommended fertilization and straw return to fields with $3000 \mathrm{~kg} \mathrm{hm}-2$; and NPK2S, recommended fertilization and straw return to fields with $6000 \mathrm{~kg} \mathrm{hm}-2$ )
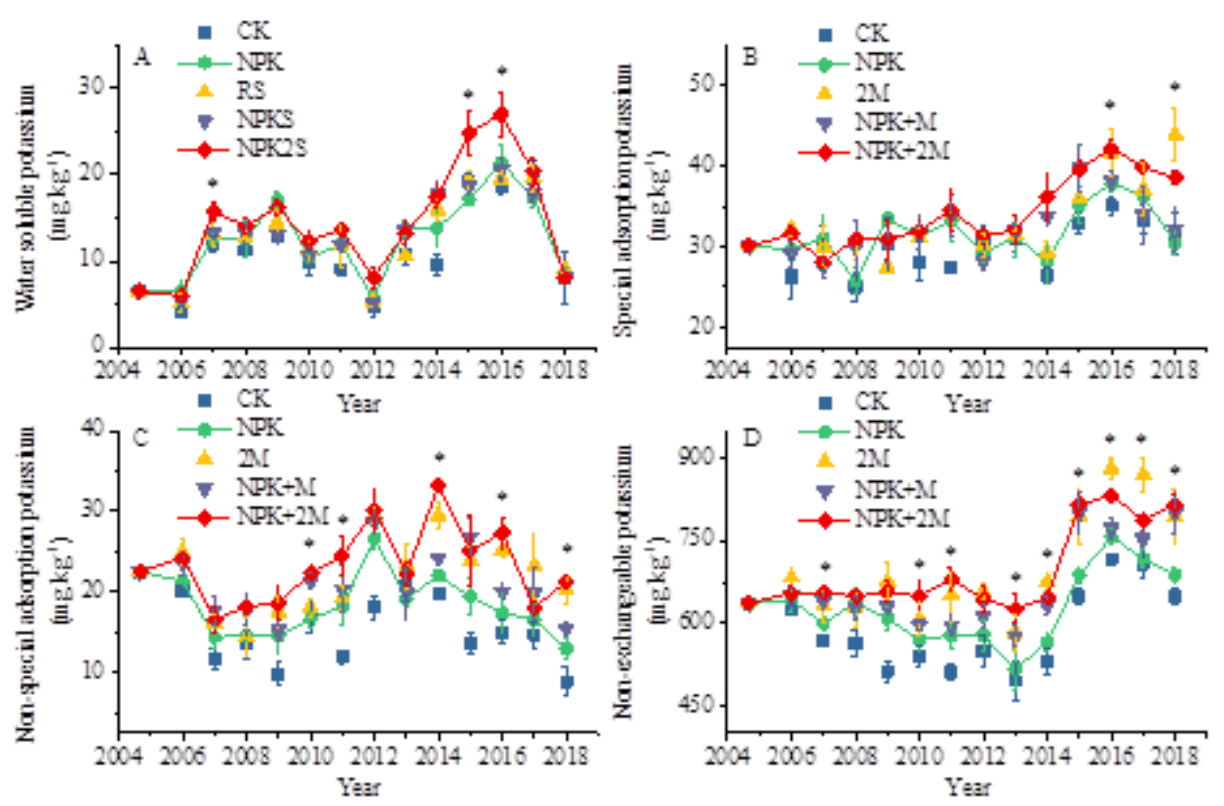

Figure 2 
Dynamics of water soluble potassium (A), special adsorption potassium (B), non-special adsorption potassium (C), and non-exchangeable potassium (D) from 2005 to 2018. (CK, no fertilization and straw; NPK, recommended fertilization and no straw return; RS, no fertilization and straw return to fields with $6000 \mathrm{~kg} \mathrm{hm}-2$, NPKS, recommended fertilization and straw return to fields with $3000 \mathrm{~kg} \mathrm{hm}-2$; and NPK2S, recommended fertilization and straw return to fields with $6000 \mathrm{~kg} \mathrm{hm}-2$. The significance levels between NPK2S and NPK are given (* $p<0.05)$.)
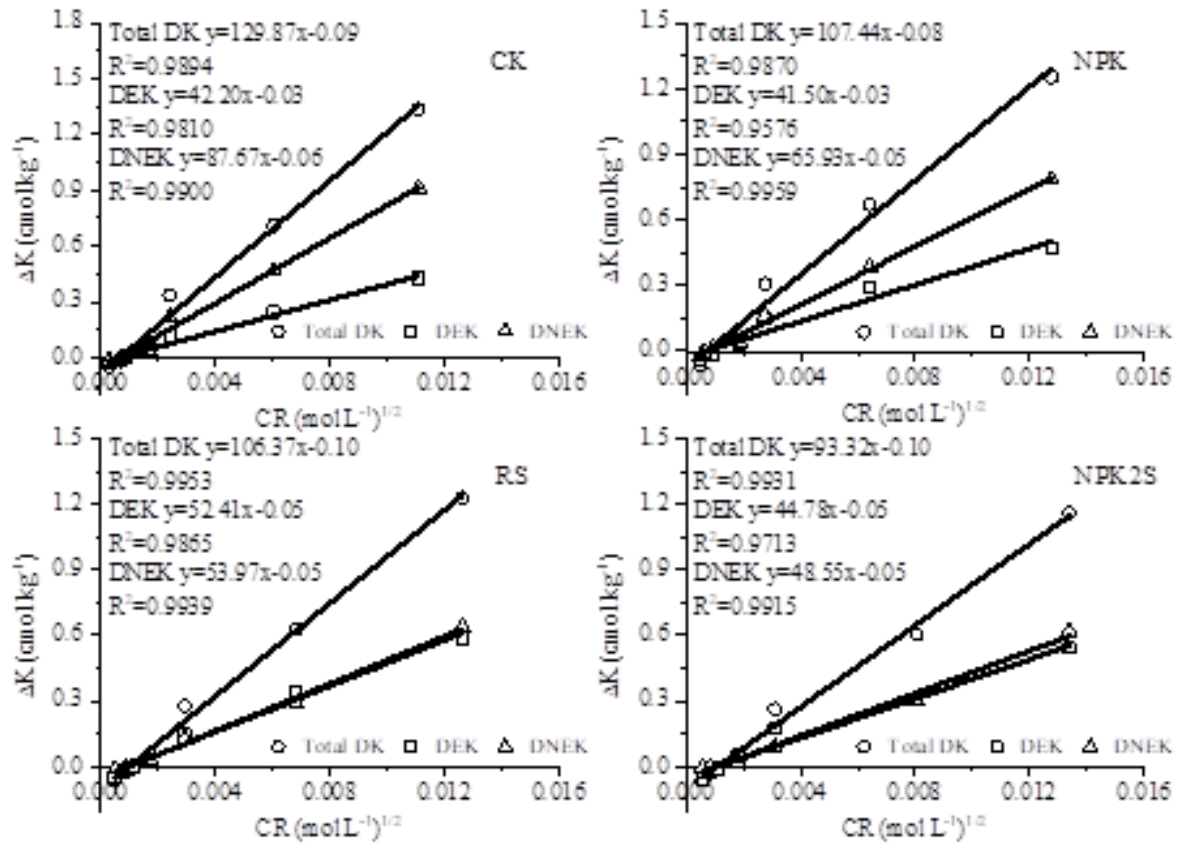

\section{Figure 3}

Plots of $\Delta K$ vs. CR for tested soils with or without straw return. (CK, no fertilization and straw; NPK, recommended fertilization and no straw return; RS, no fertilization and straw return to fields with $6000 \mathrm{~kg}$ $\mathrm{hm}-2$, NPK2S, recommended fertilization and straw return to fields with $6000 \mathrm{~kg} \mathrm{hm}-2$; Total DK or $\Delta \mathrm{K}$, amount of total $\mathrm{K}$ adsorbed or release from soil during equilibration; $\mathrm{CR}$, potassium concentration ratio, $\mathrm{DEK}$, amount of $\mathrm{K}$ adsorbed or release due to exchangeable pool of $\mathrm{K}$ during equilibration, $\mathrm{DENK}$, amount of $\mathrm{K}$ adsorbed or release due to non-exchangeable pool of $\mathrm{K}$ during equilibration) 

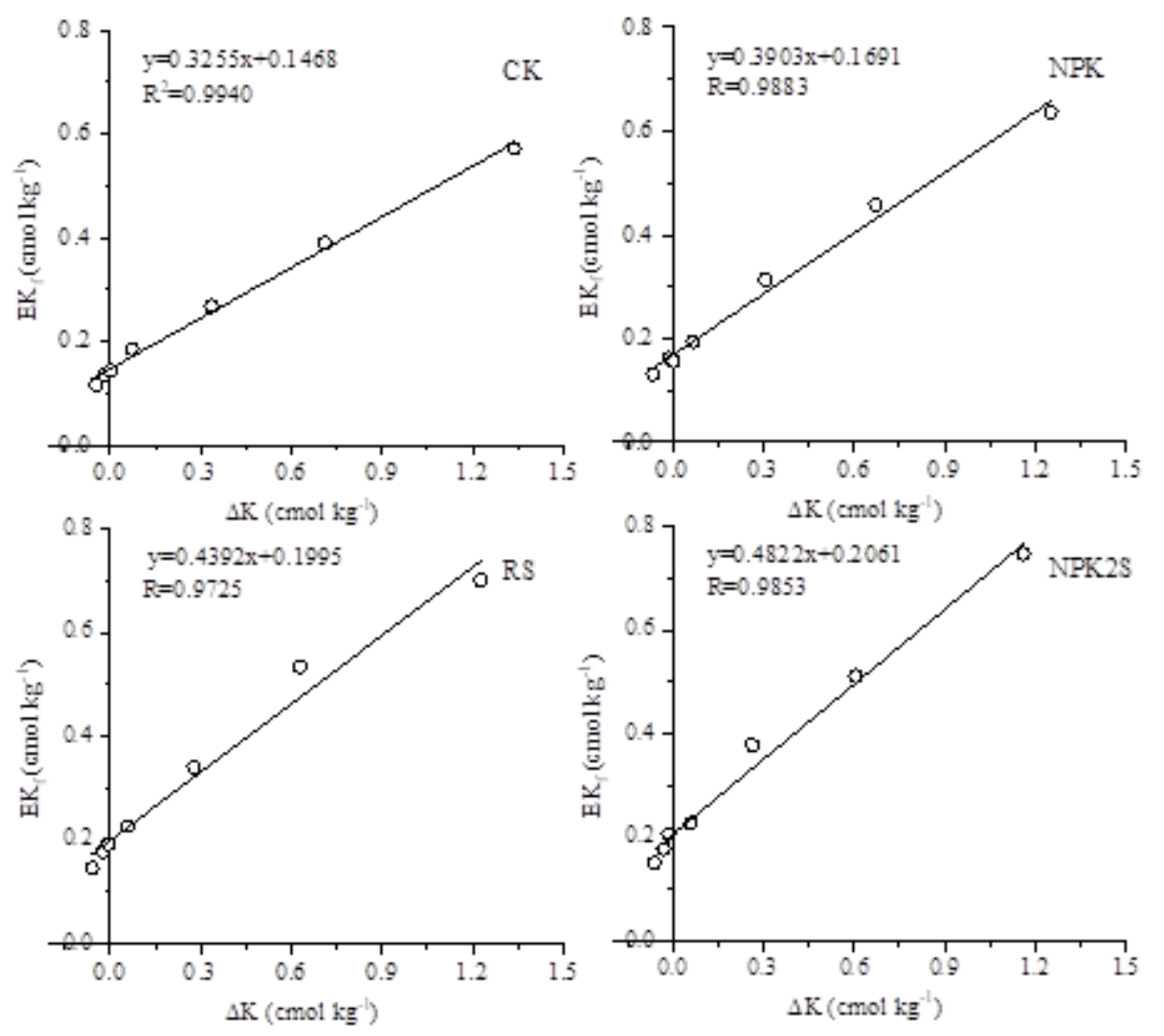

Figure 4

Plots of EKf vs. $\Delta \mathrm{K}$ for tested soils with or without straw return. (CK, no fertilization and straw; NPK, recommended fertilization and no straw return; RS, no fertilization and straw return to fields with $6000 \mathrm{~kg}$ $\mathrm{hm}-2$, NPK2S, recommended fertilization and straw return to fields with $6000 \mathrm{~kg} \mathrm{hm}-2$; EKf, NH4OAc extractable $\mathrm{K}$ determined after equilibration period; $\Delta \mathrm{K}$, amount of total $\mathrm{K}$ adsorbed or release from soil during equilibration) 

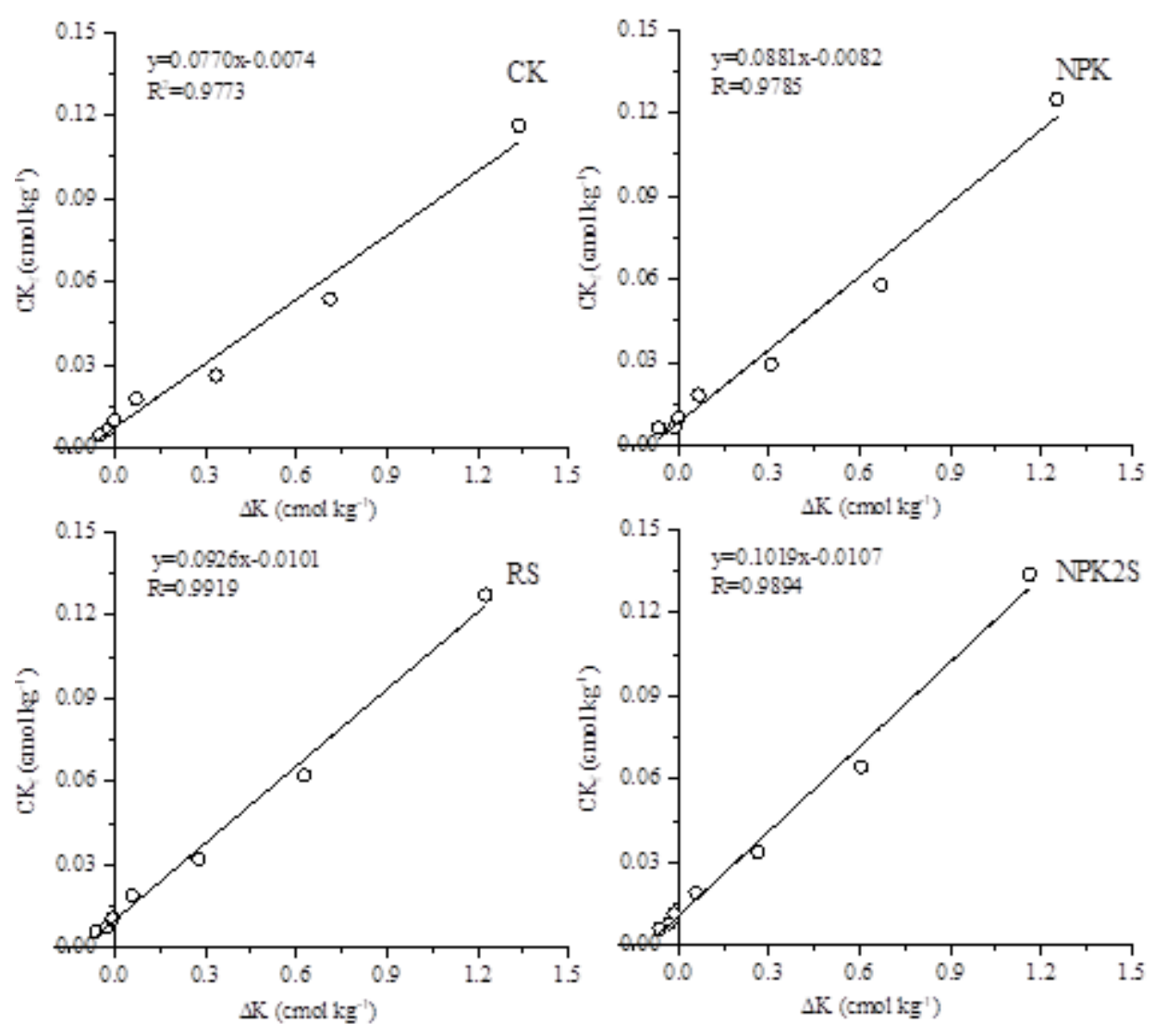

\section{Figure 5}

Plots of CKf vs. $\Delta K$ for tested soils with and without straw return. (CK, no fertilization and straw; NPK, recommended fertilization and no straw return; RS, no fertilization and straw return to fields with $6000 \mathrm{~kg}$ hm-2, NPK2S, recommended fertilization and straw return to fields with $6000 \mathrm{~kg} \mathrm{hm}-2 ;$ CKf, Potassium concentration in soil solution after equilibration period; $\Delta \mathrm{K}$, amount of total $\mathrm{K}$ adsorbed or release from soil during equilibration) 

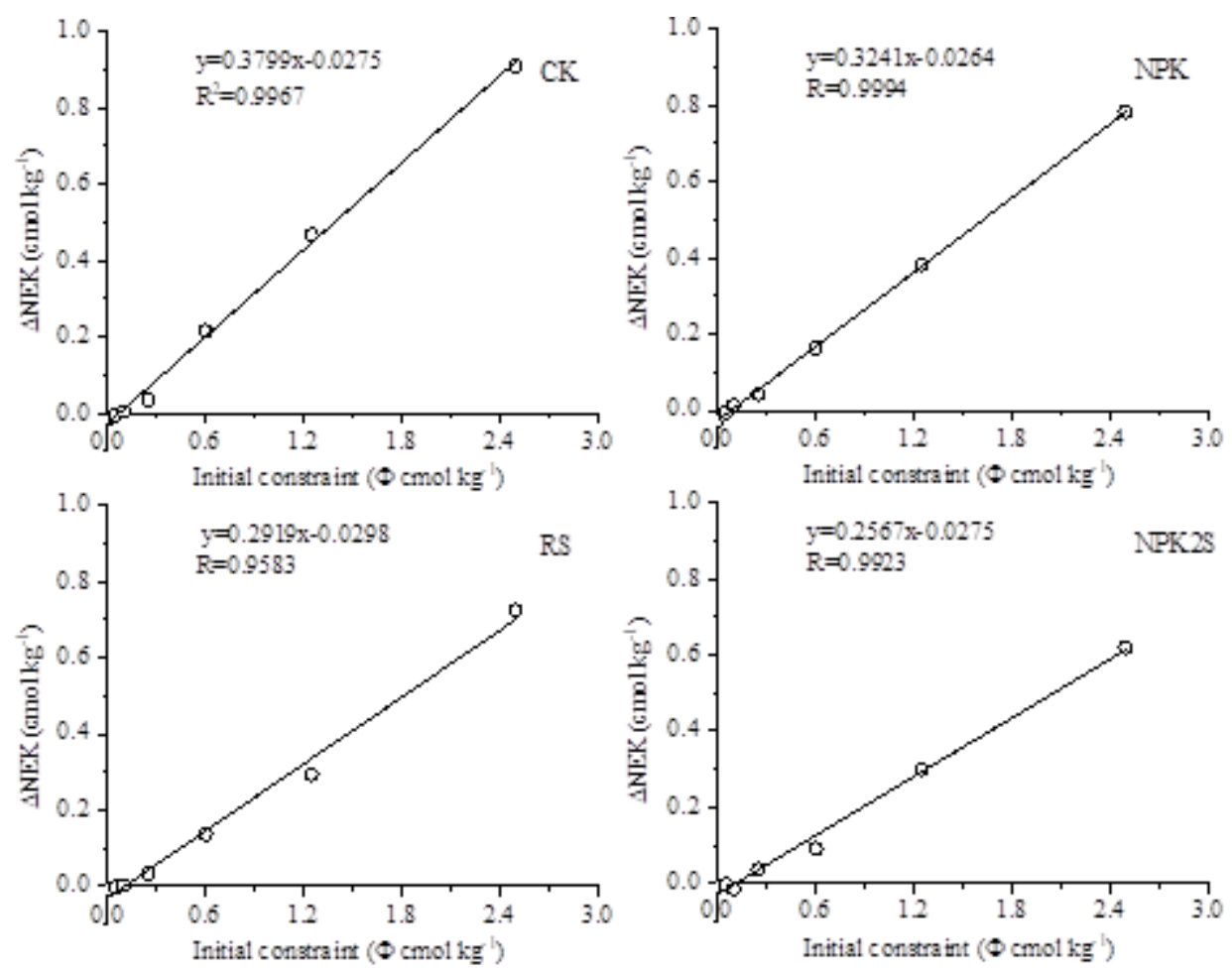

\section{Figure 6}

Plots of $\triangle N E K$ vs. initial constraint $\mathrm{K}$ for tested soils with and without straw return. (CK, no fertilization and straw; NPK, recommended fertilization and no straw return; RS, no fertilization and straw return to fields with $6000 \mathrm{~kg} \mathrm{hm}-2$, NPK2S, recommended fertilization and straw return to fields with $6000 \mathrm{~kg} \mathrm{hm}-2$; $\triangle \mathrm{NEK}$, amount of $\mathrm{K}$ adsorbed or release due to non-exchangeable pool of $\mathrm{K}$ during equilibration)
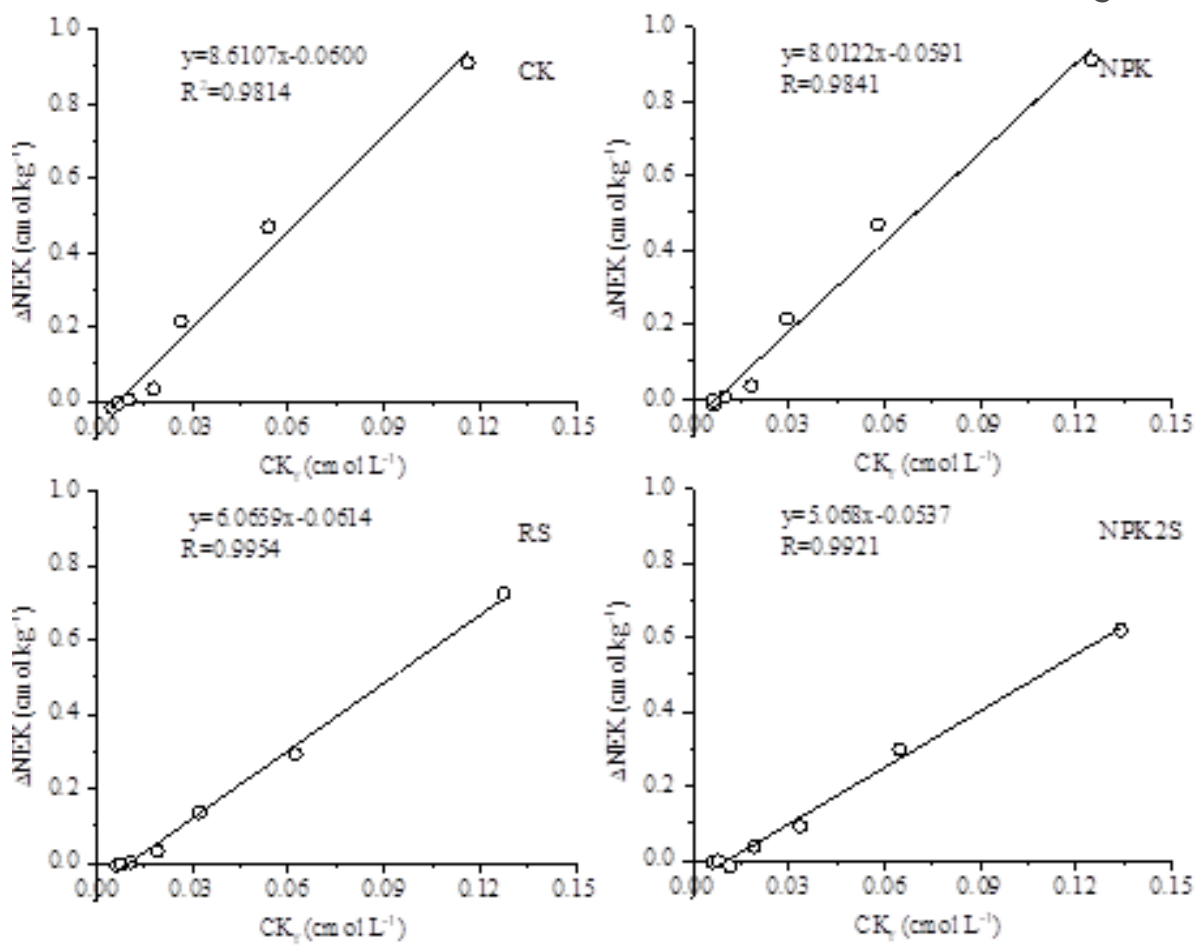

Figure 7 
Plots of $\triangle$ NEK vs. CKf for tested soils with and without straw return. (CK, no fertilization and straw; NPK, recommended fertilization and no straw return; RS, no fertilization and straw return to fields with $6000 \mathrm{~kg}$ $\mathrm{hm}-2$, NPK2S, recommended fertilization and straw return to fields with $6000 \mathrm{~kg} \mathrm{hm}-2 ; \Delta \mathrm{NEK}$, amount of $\mathrm{K}$ adsorbed or release due to non-exchangeable pool of $\mathrm{K}$ during equilibration; $\mathrm{CKf}$, Potassium concentration in soil solution after equilibration period)
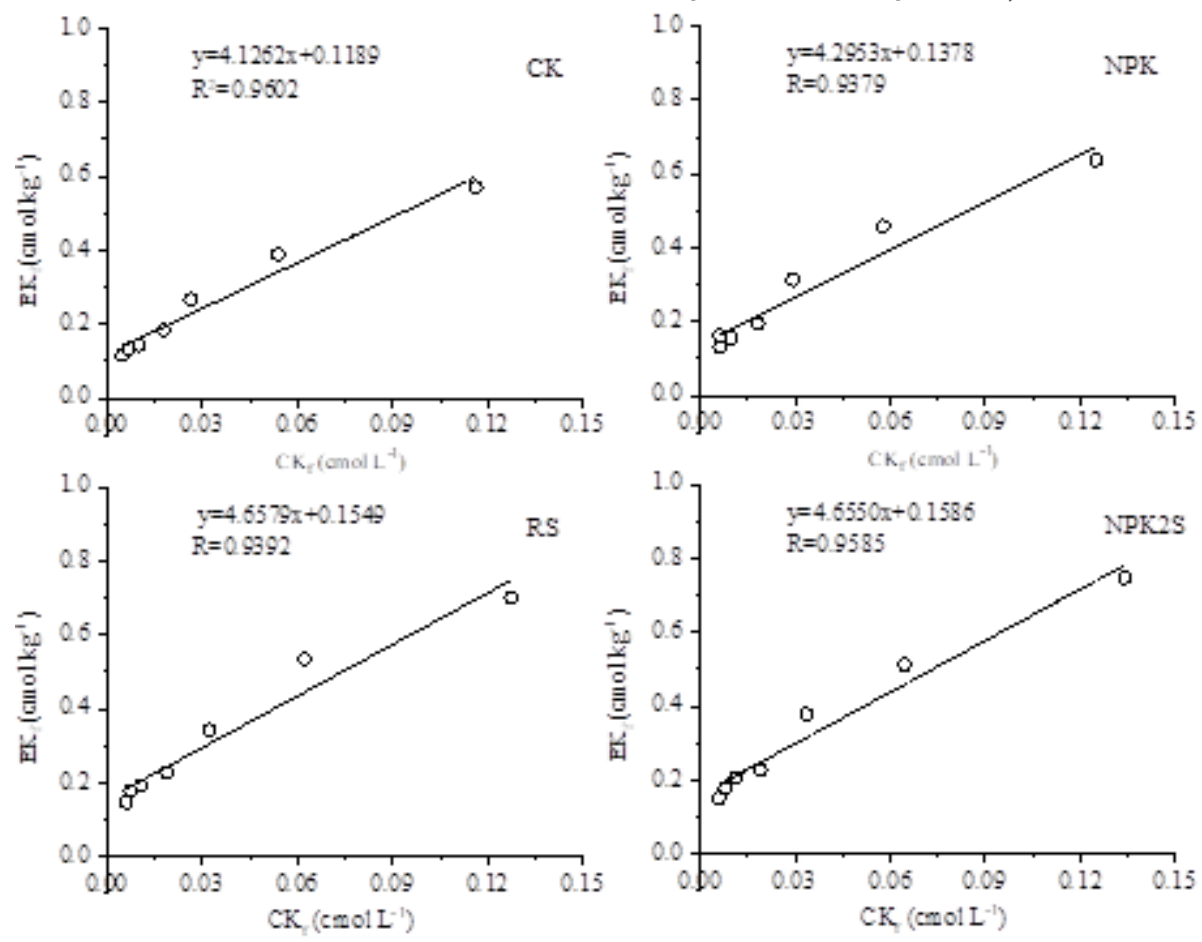

\section{Figure 8}

Plots of EKf vs. CKf for tested soils with and without straw return. (CK, no fertilization and straw; NPK, recommended fertilization and no straw return; RS, no fertilization and straw return to fields with $6000 \mathrm{~kg}$ $\mathrm{hm}-2, \mathrm{NPK} 2 \mathrm{~S}$, recommended fertilization and straw return to fields with $6000 \mathrm{~kg} \mathrm{hm}-2$; EKf, NH4OAc extractable $\mathrm{K}$ determined after equilibration period; CKf, Potassium concentration in soil solution after equilibration period) 

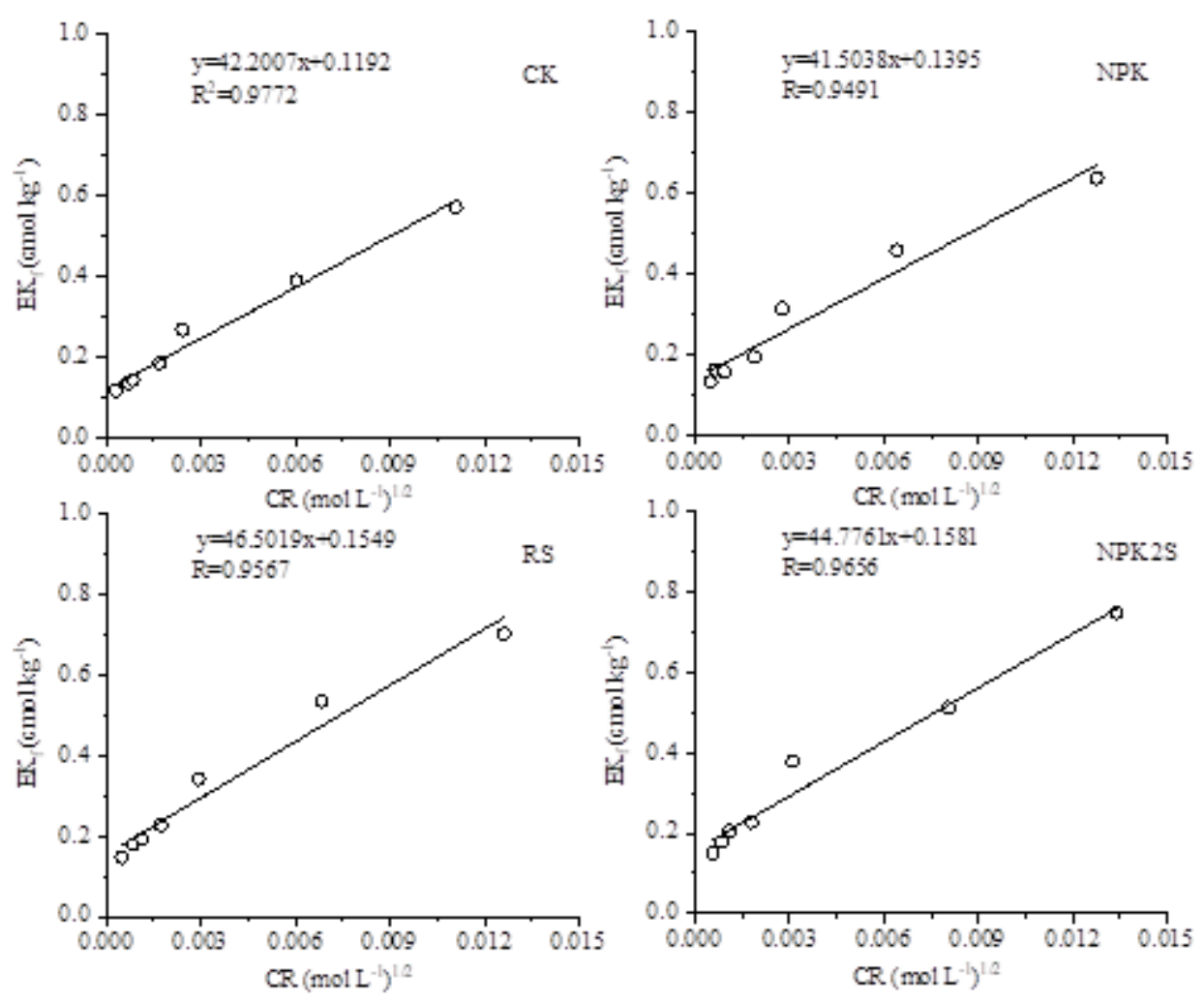

\section{Figure 9}

Plots of EKf vs. CR for tested soils with and without straw return. (CK, no fertilization and straw; NPK, recommended fertilization and no straw return; RS, no fertilization and straw return to fields with $6000 \mathrm{~kg}$ $\mathrm{hm}-2$, NPK2S, recommended fertilization and straw return to fields with $6000 \mathrm{~kg} \mathrm{hm}-2$; EKf, NH4OAc extractable $\mathrm{K}$ determined after equilibration period; $\mathrm{CR}$, potassium concentration ratio)

\section{Supplementary Files}

This is a list of supplementary files associated with this preprint. Click to download.

- Supplementmaterial.docx 